\title{
The Flow Generator Relations for Water Renewal through the Flushing Culverts in Marinas
}

\author{
Ivana Bartolić $^{1, *}$, Goran Lončar ${ }^{2}$, Damjan Bujak ${ }^{2}$ and Dalibor Carević $^{2}$ \\ 1 Department of Civil Engineering, Zagreb University of Applied Sciences, 10010 Zagreb, Croatia \\ 2 Department of Water Research, Faculty of Civil Engineering, University of Zagreb, 10000 Zagreb, Croatia; \\ gloncar@grad.hr (G.L.); dbujak@grad.hr (D.B.); car@grad.hr (D.C.) \\ * Correspondence: ibartolic@tvz.hr; Tel.: +385-99-376-2469
}

Received: 30 May 2018; Accepted: 10 July 2018; Published: 13 July 2018

\begin{abstract}
An understanding of the relationship between the flow generators and harbor design could result in an acceptable seawater renewal into an enclosed basin. The flushing culverts located in the breakwater are the most cost-effective technique for improving water renewal in port engineering. The aim of the paper was to identify and quantify the relation between flow generators and culvert flow to propose an optimal position for the flushing culverts. Mentioned relations are important for designing and positioning the flushing culverts in marinas to achieve optimal sea exchange in the marina basin. Field measurements in the marina Opatija were performed and the data served for calibrating a 3D circulation model and a wave generation/propagation model. The absolute volume of the flow through the culverts caused by wind waves has the more important contribution to the water renewal in the marina basin than the coastal springs have. The optimal flow rates through the culverts are performed by positioning the flushing culvert axis at the mean sea level in accordance with the main incident direction of the propagating waves.
\end{abstract}

Keywords: seawater renewal; flushing culverts; wind waves; coastal springs

\section{Introduction}

The fraction of people inhabiting the seashore is projected to rise from the present $60 \%$ to $75 \%$ by the year 2025, and the population as a whole is also anticipated to grow to 11.1 billion people by the year $2100[1,2]$. With the growth of the inhabitants and metropolitan areas near the shore, an anthropogenic pressure to the marine environment is also on the rise. Coastal infrastructure scattered along the shoreline are often pivotal points where the water quality is under biggest threat from anthropogenic activities [3]. Communities use ports in the vicinity of cities to trade goods, hence during cargo manipulation unanticipated accidents may well occur [4]. In the sea, near densely populated areas, further possibly harmful pollutants could accumulate as a consequence of human activity. Harmful bacteria like E. coli, heavy metals like copper and pesticides are likely to be deposited in the seabed sediment which poses a threat to both human and animal life at sea, especially if dredging or seabed erosion resuspends them again [5-8]. Stagnant seawater regularly is characterized by a reduction in dissolved oxygen, which favors the growth of harmful algal blooms and afterward could further compromise the marine ecosystem $[9,10]$. Pollution concentrations should be continuously monitored at sensitive coastal locations, to prevent the undesirable effects of various pollutants. Harmful effects of high pollutant concentrations within a semi-enclosed basin can be avoided if a sufficient water renewal rate is upheld or the sources of pollution are prevented [11]. Water renewal in semi-enclosed basins has proved to be a critical aspect influencing the pollutant concentrations and therefore life in a marine ecosystem [12]. The water renewal rate in human-made or naturally enclosed basins is conditioned by seawater circulation generators (e.g., wind, waves, tidal oscillations, inner freshwater 
discharge, etc.). An understanding of the relationship between the flow generators and harbor design could result in an acceptable seawater renewal with the purpose of reducing pollution concentrations introduced into an enclosed basin [13].

Previous scientific research offers mathematical procedures to compute the seawater renewal efficiency of a semi-enclosed basin, frequently grounded either on hydrodynamic or morphological features. Most approaches for seawater renewal estimation are fundamentally built around tidal oscillations as the dominant generator of water circulation inside enclosed basins [14-16]. The structural features such as the planform geometry of a port, inlet width, water depth, bed slope and so forth, also influence the water renewal efficiency [15-18]. In regions where the tidal oscillation range is considerably small like the Mediterranean and the Adriatic Sea, the water renewal is also consequently reduced substantially. In these areas, it is widespread to use openings or flushing culverts (pipes or rectangular openings in a breakwater) with the aim of improving the water exchange capacity of the basin $[19,20]$. Flushing culverts are regarded as the most cost-effective technique for improving water renewal in port engineering. Its purpose is to improve the water renewal within an enclosed basin harnessing also other flow generators like wind and waves, without allowing undesirable wave energy to come into and disturb the port basin. Optimal opening layouts design can be achieved by taking into account two basic yet contradicting criteria, i.e., the water renewal and the wave energy penetration into the harbor [21].

Wind action and waves have also been identified to have a significant influence on the seawater renewal. Research making use of numerical models, established to study the Venice lagoon seawater circulation, demonstrated a valuable improvement of seawater renewal (in two inlet basins) with the manifestation of a local sea level tilt within the basin produced by wind stress [22]. Once the slope is formed, steady circulation is established where seawater moves toward the northern inlet, significantly improving water renewal through the whole basin [23]. Other research concluded that wind is not meaningfully impacting the water renewal in restricted one inlet basins where the wind is, for the most part, mixing the confined seawater in comparison to the Venice lagoon that has multiple inlets [22,24].

Experimental work was conducted in a laboratory flushing culvert model with the aim of estimating the water velocity inside the culverts and wave transmission coefficients regarding significant wave height, wave period, sea level, culvert diameter and length [25,26]. This laboratory experimental work could not take into consideration other natural generators like tides and winds, but only wave action and, therefore, in this paper the interaction between waves and other natural generators will be examined as well as the relative influence of waves on the general flow pattern through the flushing culverts. Other research has attempted to evaluate the effect of a culvert layout design on the culvert water exchange efficiency when the waves were not taken into consideration [19]. The culvert position, opposite to the main harbor entrance, was recognized as optimal for the marina flushing.

This paper presents results of field measurements in the marina Opatija, which has embedded eight culvert pipes in the main breakwater. The aim was to recognize and quantify the relation between flow generators to propose an optimal position for the flushing culverts. The measured data was analyzed and served as data for the 3D circulation model calibration and a wave generation/propagation model. The numerical model of wave generation was calibrated to evaluate a contribution of wave activity at the location of the marina Opatija during 10 years.

The article structure is shown in the Figure 1. 


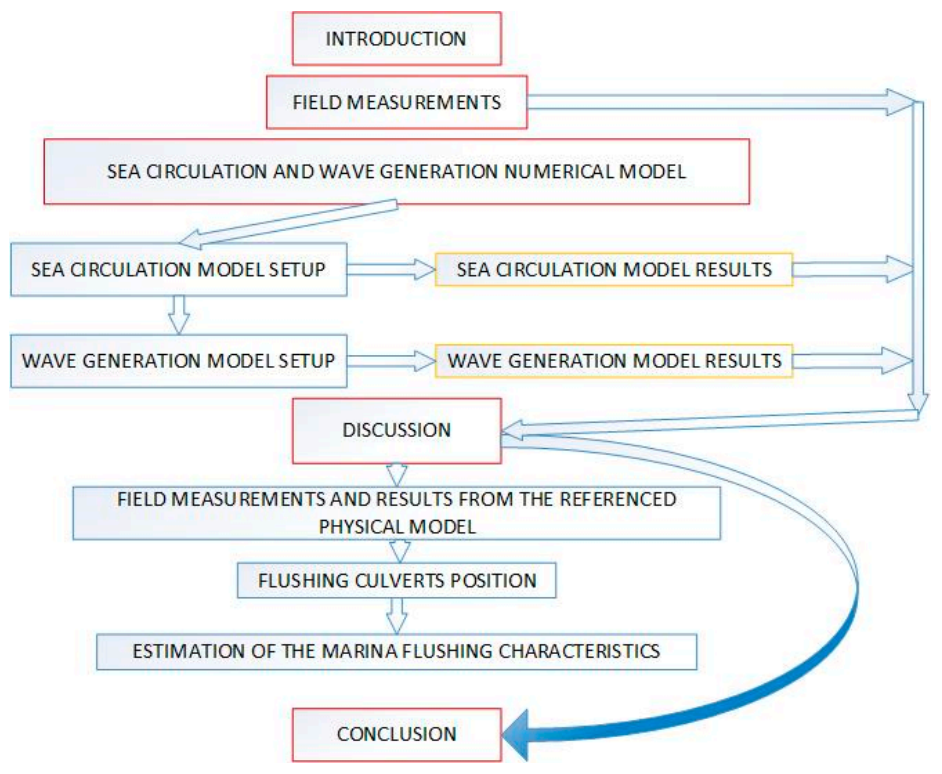

Figure 1. The article flow chart.

\section{Field Measurements}

Field measurements were performed inside and in the vicinity of ACI Marina Opatija $\left(45^{\circ} 19^{\prime} / 14^{\circ} 17.7^{\prime}\right)$ in northern Croatia, near the city of Rijeka (Figure 2). The marina is linked to the Adriatic Sea with a $30 \mathrm{~m}$ wide inlet (marina entrance). In the primary breakwater, eight parallel flushing culverts (circular cross sections with a $1 \mathrm{~m}$ diameter) are embedded to improve water renewal inside the basin. The mean marina depth is approximately $5 \mathrm{~m}$, with the depth decreasing in the vicinity of the breakwater.
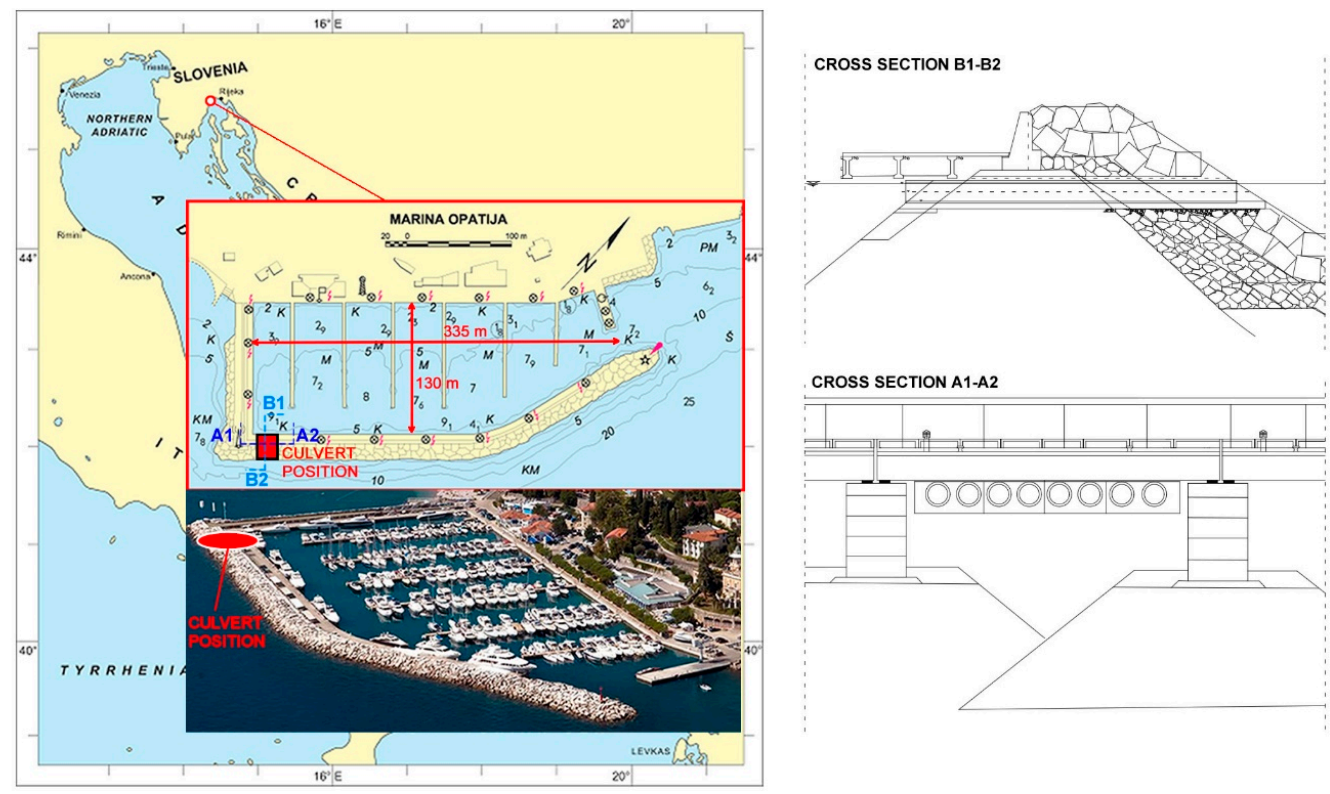

Figure 2. Situation map and figure of ACI marina Opatija.

Detailed bathymetry surveillance was conducted in the marine area, to establish a sea circulation numerical model. Oceanographic parameters (current velocity and direction, salinity, sea temperature, significant wave height, sea level) were monitored during the winter (15 February 2017-20 March 2017) and summer (4 July 2017-29 August 2017) measurement periods at several locations at the ACI 
marina Opatija basin (Figure 3). Obtained data sets were utilized in order to define the initial conditions, boundary conditions and to verify the numerical model results. Currents and the sea surface elevation (Figure 4) were monitored continuously during the winter and summer measurement periods with the use of five Acoustic Doppler Current Profilers (ADCP at positions 1-5) (Figure 3). For the duration of the summer measurement period, all the devices were positioned at the same locations as during the winter except ADCP 3, which was repositioned next to ADCP 4 at the marina entrance in an attempt to estimate the flow rate through the entrance inlet. The sea temperature $(T)$ and salinity $(S)$ were measured throughout the vertical sea column at sites 1-4 nearby the marina basin (Figure 3), during measuring device deployment and recovery. Wave conditions (significant wave heights $H_{S}$, peak period $T_{P}$ and incident wave direction, Figure 5) were obtained using ADCPs at station 1 and 2 (Figure 3). The PCM device (Pro Flow Meter for portable ultrasonic flow measurements) was located at the entrance of one flushing culvert (station 2, Figure 3) and used for culvert-flow rate measurements. A positive flow rate through the flushing culvert was assigned to inflows into the marina and negative to outflows from the marina. A CTD device (Conductivity/Temperature/Depth, Teledyne Marine group, Poway, CA, USA) was fixed at site 2, next to the flushing culvert, in order to measure temperature and salinity during measurement periods. Data regarding wind velocities were obtained from an anemometer (positioned on the lighthouse at the head of the breakwater) $10 \mathrm{~m}$ above the ground (Figures 3 and 5). Sampling resolutions of deployed instruments are shown in Table 1. The data on precipitation (Figure 4) was obtained from a local meteorological station located near the marina (Rijeka station, $\phi=45^{\circ} 20^{\prime}, \lambda=14^{\circ} 27^{\prime}$ ).

Table 1. Sampling resolution of the instruments deployed at the marina Opatija.

\begin{tabular}{ccc}
\hline Instrument & Sampling Rate & Output (Averaging) \\
\hline ADCP 1,2 & $1 \mathrm{~s}$ & Wave-15 min \\
ADCP $3,4,5$ & $1 \mathrm{~s}$ & Currents-10 min \\
CTD & $1 \mathrm{~s}$ & Currents-10 min \\
Anemometer & $1 \mathrm{~s}$ & $10 \mathrm{~min}$ \\
PCM & Varies with hydraulic and physical conditions & $10 \mathrm{~min}$ \\
\hline
\end{tabular}

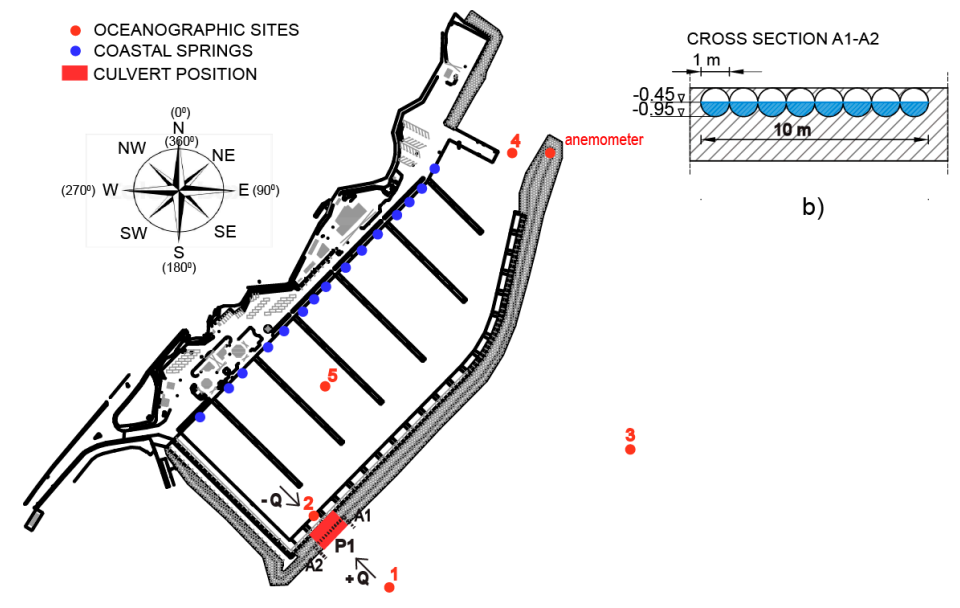

a)

Figure 3. (a) Plan view of the oceanographic sites in the marina (ADCP 1-5-sea current and surface elevation measurements, ADCP 1, 2-wave parameters measurements, 2-PCM and CTD device, 1-5 vertical temperature and salinity profile), the coastal spring positions, the culvert position P1 and; (b) cross sections through the flushing culverts. 

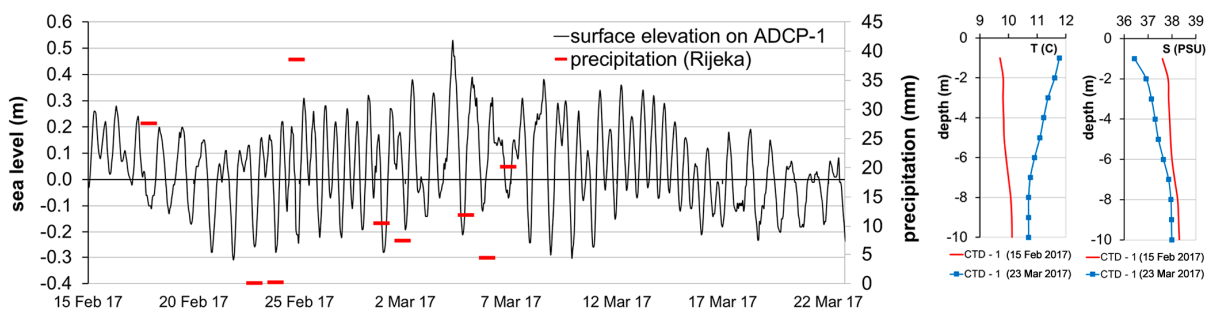

a)
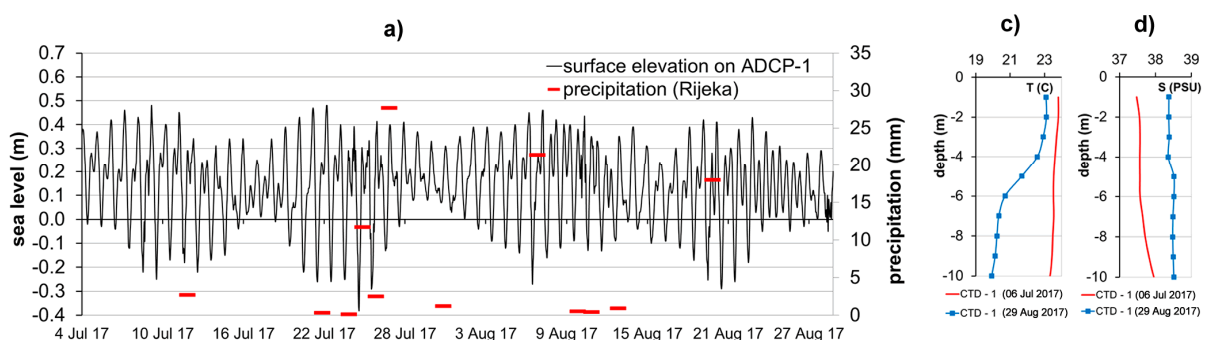

b)

e)

f)

Figure 4. Time series of surface elevations recorded at the ADCP station 1 and daily precipitation at the meteorological station Rijeka $\left(\phi=45020^{\prime}, \lambda=14027^{\prime}\right)$ for the (a) winter and (b) summer measurement periods; the sea temperature $(T)$ and salinity $(S)$ throughout the vertical sea column at site 1 for $(\mathbf{c}, \mathbf{d})$ the winter and $(\mathbf{e}, \mathbf{f})$ summer measurement periods.
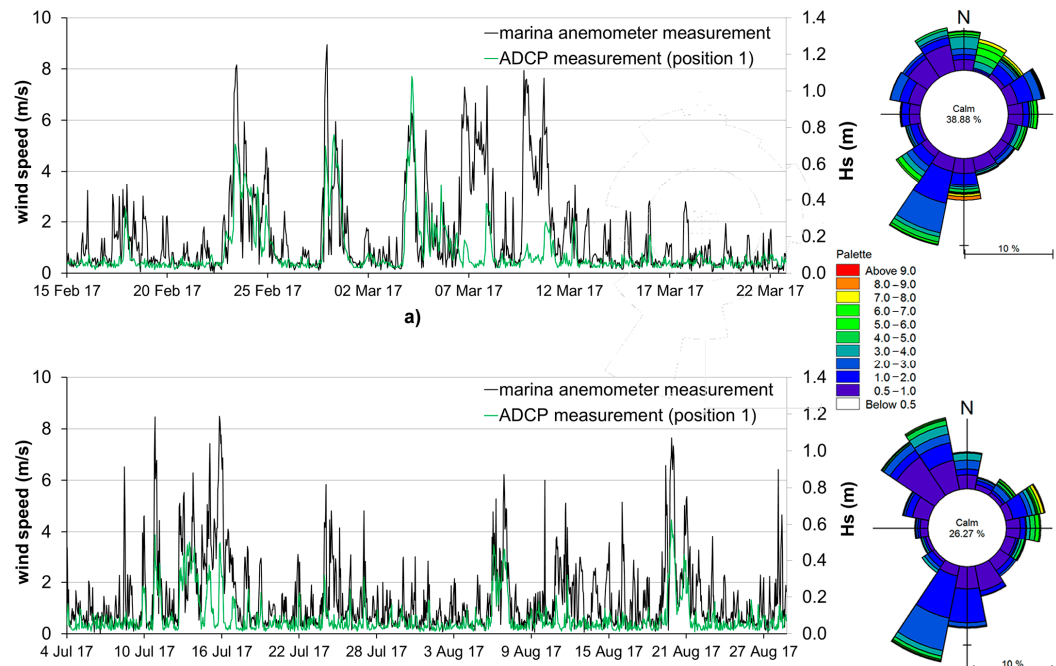

b)

Figure 5. Time series of wind velocities and significant wave heights (measured at position 1, hourly averaged) with the corresponding wind rose for the (a) winter and (b) summer measurement periods.

The incident wind waves approaching the marina in a band from $90^{\circ}$ (E) to $180^{\circ}$ (S) provide the most intense culvert inflow (marked by red line in Figure 6). During the winter and summer measurement periods, noteworthy wave situations were documented (Tables 2 and 3) assuming the criteria: $H_{S} \geq 0.3 \mathrm{~m}, T_{P} \geq 2.8 \mathrm{~s}$ and incident wave direction in the band from $90^{\circ}$ (E) to $180^{\circ}$ (S), measured at the ADCP station 1. A total of seven wave situations were acknowledged during the winter period (Table 2) and 10 in the course of the summer measurement periods (Table 3). The starting date of each proper situation, its duration, corresponding average significant wave height, peak period and maximum significant wave height are listed in Tables 2 and 3. The relevant wave conditions are also indicated in Figure 6. In the course of the winter, waves ranging from $100^{\circ}$ to $174^{\circ}$ caused an increased culvert inflow $+Q_{P C M}\left(+Q_{P C M}\right.$ denotes inflow-seawater entering into the marina basin Figure 3$)$. 


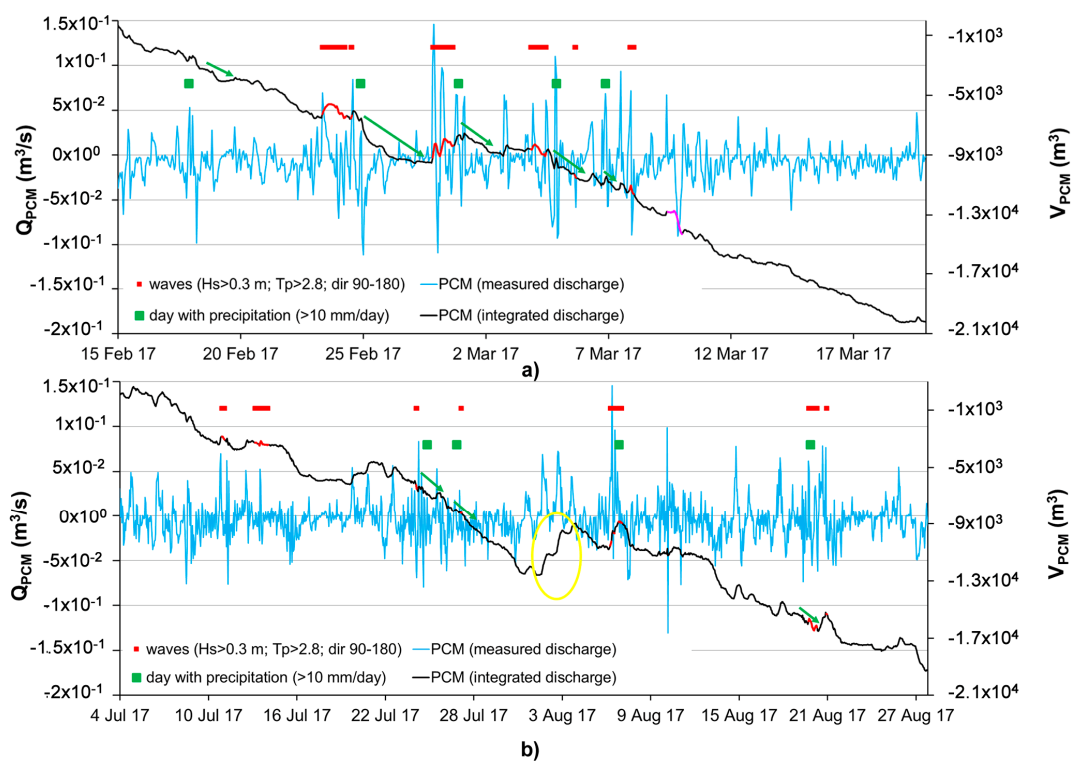

Figure 6. Time series of measured and integrated culvert discharges for the one culvert pipe measured by the PCM device; wave situations characterized by the significant wave height $H_{S} \geq 0.3 \mathrm{~m}$, peak periods $T_{P} \geq 2.8 \mathrm{~s}$ in the range from $90^{\circ}$ to $180^{\circ}$ (marked by red line), days with precipitation intensity $>10 \mathrm{~mm} /$ day (marked by green arrows), specific situations explained in text marked by magenta line and yellow circle for the (a) winter and (b) summer measurement periods.

Table 2. Start date of each relevant wave situation (adopted criteria $H_{S} \geq 0.3 \mathrm{~m} ; T_{P} \geq 2.8 \mathrm{~s}$; incident waves ranging from $90^{\circ}$ to $180^{\circ}$ ), its duration, corresponding average significant wave height, peak period, maximum significant wave height and as wave direction recorded at ADCP 1 for the winter period.

\begin{tabular}{ccccccc}
\hline \multirow{2}{*}{ Winter Measurement Campaign } & \multicolumn{5}{c}{ Deepwater Conditions } \\
\cline { 3 - 7 } & Duration & $\boldsymbol{H}_{S-A V}$ & $\boldsymbol{T}_{\boldsymbol{P}-\boldsymbol{A V}}$ & $\boldsymbol{H}_{S-M A X}$ & $\boldsymbol{d i r}_{\boldsymbol{A} V}$ \\
\hline & Situation Onset & $(\mathbf{h})$ & $\mathbf{( m )}$ & $\mathbf{( s )}$ & $\mathbf{( m )}$ & $\left.\mathbf{(}^{\circ}\right)$ \\
\hline 1 & 23 February 2017 23:00 & 23 & 0.51 & 3.60 & 0.71 & 165 \\
2 & 25 February 2017 3:00 & 2 & 0.45 & 3.50 & 0.47 & 100 \\
3 & 28 February 2.2017 11:00 & 21 & 0.55 & 3.64 & 0.76 & 159 \\
4 & 4 March 2017 11:00 & 16 & 0.65 & 4.41 & 1.08 & 161 \\
5 & 6 March 2017 6:00 & 2 & 0.42 & 5.40 & 0.48 & 174 \\
6 & 8 March 2017 12:00 & 5 & 0.35 & 2.90 & 0.38 & 105 \\
7 & 12 March 2017 20:00 & 2 & 0.30 & 2.85 & 0.30 & 103 \\
\hline
\end{tabular}

Table 3. Start date of each relevant wave situation (adopted criteria $H_{S} \geq 0.3 \mathrm{~m} ; T_{P} \geq 2.8 \mathrm{~s}$; incident waves ranging from $90^{\circ}$ to $180^{\circ}$ ), its duration, corresponding average significant wave height, peak period, maximum significant wave height and as wave direction recorded at ADCP 1 for the summer period.

\begin{tabular}{ccccccc}
\hline \multirow{2}{*}{ Summer Measurement Campaign n } & \multicolumn{5}{c}{ Deepwater Conditions } \\
\cline { 3 - 7 } & Situation Onset & Duration & $\boldsymbol{H}_{S-A V}$ & $\boldsymbol{T}_{\boldsymbol{P}-A V}$ & $\boldsymbol{H}_{S-M A X}$ & $\boldsymbol{d i r}_{A V}$ \\
\hline & 11 July 2017 11:00 & 2 & $(\mathbf{m})$ & $\mathbf{( s )}$ & $\mathbf{( m )}$ & $\left.\mathbf{(}^{\circ}\right)$ \\
\hline 1 & 13 July 2017 17:00 & 4 & 0.45 & 2.91 & 0.55 & 169 \\
2 & 13 July 2017 23:00 & 16 & 0.40 & 2.83 & 0.44 & 97 \\
3 & 24 July 2017 15:00 & 2 & 0.30 & 2.07 & 0.46 & 104 \\
4 & & & & & 0.32 & 181 \\
\hline
\end{tabular}


Table 3. Cont.

\begin{tabular}{|c|c|c|c|c|c|c|}
\hline \multirow{2}{*}{\multicolumn{2}{|c|}{ Summer Measurement Campaign }} & \multicolumn{5}{|c|}{ Deepwater Conditions } \\
\hline & & \multirow{2}{*}{$\begin{array}{c}\text { Duration } \\
\text { (h) }\end{array}$} & \multirow{2}{*}{$\begin{array}{c}H_{S-A V} \\
(\mathrm{~m})\end{array}$} & \multirow{2}{*}{$\begin{array}{c}T_{P-A V} \\
(\mathrm{~s})\end{array}$} & \multirow{2}{*}{$\begin{array}{c}H_{S-M A X} \\
\text { (m) }\end{array}$} & \multirow{2}{*}{$\begin{array}{c}\operatorname{dir}_{A V} \\
\left(^{\circ}\right)\end{array}$} \\
\hline & Situation Onset & & & & & \\
\hline 5 & 27 July 2017 16:00 & 2 & 0.30 & 2.68 & 0.31 & 175 \\
\hline 6 & 6 August 2017 19:00 & 3 & 0.30 & 3.31 & 0.34 & 108 \\
\hline 7 & 7 August 2017 1:00 & 2 & 0.30 & 3.3 & 0.34 & 108 \\
\hline 8 & 7 August 2017 10:00 & 5 & 0.43 & 2.74 & 0.43 & 111 \\
\hline 9 & 20 August 2017 6:00 & 15 & 0.44 & 3.11 & 0.48 & 105 \\
\hline 10 & 21 August 2017 11:00 & 2 & 0.38 & 2.93 & 0.43 & 104 \\
\hline
\end{tabular}

Northeastern wind generates wave fields parallel to the main breakwater with lower significant wave heights and periods (Figure 5) (situation: 7 March and 10 March, Figure 5) wherein a culvert inflow is absent. The winds could cause currents parallel to the main breakwater and in consequence raise the sea surface elevation in the SW part of the marina, where culverts are constructed, so greater outflow could occur (situation on 10 March, marked by magenta line-Figure 6). Contrary to expectations, during a period of low wind velocities in the summer period (from 2 August to 4 August marked by yellow circle-Figure 6), a dominant culvert inflow was observed. It is probably a result of the specific flow pattern in the bay of Rijeka that influenced the unforeseen inflow.

In the Opatija area, i.e., the Ičići area, a large number of coastal springs have been documented (Figure 7). This phenomenon is a consequence of the characteristic karstic geological condition with the occurrence of surface and subsurface springs in the observed area [27]. According to the hydrological observations at one of the most dominant coastal springs Kristal, during the dry summer periods, a discharge of $500 \mathrm{~L} / \mathrm{s}$ was documented.

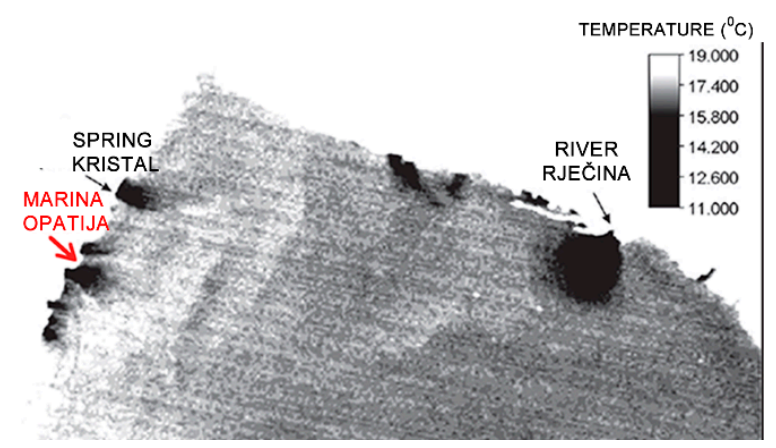

Figure 7. Position of springs according to the spatial distribution of temperature difference on 12 June 2002 [27].

During the winter measurement period, coastal spring activities were observed along the marina coastline (Figure 3). The coastal spring intensity is unknown, but visual inspection has determined its activation in days after precipitation occurrence. Further examinations showed that the spring intensity correlates with precipitation intensity. During the winter period, PCM device recorded a dominant outflow through the flushing culvert in the days after precipitation at $10 \mathrm{~mm} /$ day (marked by green arrows-Figure 6). The most intense precipitation intensity during field measurements was registered on the 25 February $(38.6 \mathrm{~mm} /$ day, Figure 4 ) when the PCM device recorded a maximum culvert outflow of $-0.112 \mathrm{~m}^{3} / \mathrm{s}$. In the summer measurement period, the effect of spring activity on the culvert outflow is not as dominant as during the winter. It is evident that after the rain on 27 July (27 mm/day), a culvert outflow is recorded, but in a reduced magnitude in comparison to the winter observations. The summer period is characterized by higher temperatures and higher evapotranspiration rates, so much more precipitation is needed for coastal spring full activation. 
Measured precipitation at the meteorological station Rijeka does not necessarily have to cause the coastal spring outflow around the marina Opatija, since the movement of the air masses, which bring precipitation, is not always in the same direction.

\section{Sea Circulation and Wave Generation Numerical Model}

\subsection{Sea Circulation Model Setup}

A three-dimensional Mike 3 FM model [28] was used in order to study the area of the marina Opatija. Its hydrodynamics are solved by utilizing the 3D RANS equations using the Boussinesq and hydrostatic approximations. The numerical model divides the domain in the vertical direction utilizing the standard sigma coordinate approach [29]. Governing equations are resolved within a finite volume grid, based on a discretization of the continuum with non-overlapping elements [30]. An approximate Riemann solver [31] is employed to compute the convective terms in the governing equations, ensuring numerical stability even in cases with steep gradients. The Smagorinsky scheme [32] and k- $\varepsilon$ models [33] are the turbulence models employed in the horizontal and vertical directions, respectively.

Simulations with the Mike 3 FM model were run using the following parameter values: minimum time step of external mode $\Delta t=0.1 \mathrm{~s}$, maximum time step of internal mode $\Delta t=30 \mathrm{~s}$, with a critical threshold CFL of 0.8 . dispersion coefficients for the temperature and salinity scalar fields were specified with a proportionality factor of 0.85 in the horizontal 0.09 in the vertical in accordance to the scaled eddy viscosity. Roughness and Smagorinsky coefficients were set as spatially and temporally constant at 0.01 and 0.2 , respectively. The wind stress coefficient which models the influence of the wind on the sea surface was defined at 0.0013 [34]. In Dalton's law, 0.5 was set for the wind coefficient and 0.9 for the evaporation coefficient. The heat flux absorption profile in the short-wave radiation is described by a modified version of Beer's law. In the surface layer, the energy absorption constant equals 0.15 , and light decay coefficient corresponds to 0.4 in the vertical direction. The hourly time series of air temperature, air humidity and cloud clearness from the nearby meteorological station Rijeka were used.

Numerical model solutions for the ACI marina Opatija domain (Figure 8) were computed using the Mike 3 FM numerical model. In the computational mesh, numerical nodes ranged from $1 \mathrm{~m}$ to $25 \mathrm{~m}$ in the horizontal, with nine additional sigma layers in the vertical direction. At position P1 (Figure 3) a composition of eight circular pipes were embedded into the breakwater, $1 \mathrm{~m}$ in diameter and $18 \mathrm{~m}$ in total length. The culvert top edge was positioned at the mean sea level (Figure 3). The breakwater is included as a non-permeable structure (no flow land boundary) having zero wave reflection. At the open boundary B-1 (Figure 8) velocities measured at ADCP station 1 are imposed to get resemblance between measured and modelled values. The measured surface elevation at ADCP 1 is used as forcing at the open boundary B-2 (Figure 8). At the boundary B-3 the normal velocity is set to zero.

At the open boundaries of the numerical model domain (B-1 and B-2) the sea temperature and vertical salinity profiles were set. These datasets were obtained with the mobile CTD device at station 1 (Figures 3 and 4) during the deployment and retrieval of measurement devices. The initial conditions were defined with current velocity values set to $0 \mathrm{~m} / \mathrm{s}$ in all three directions throughout the whole domain. For the initial conditions, a homogeneous scalar field of sea temperature and salinity in the horizontal direction has been set in agreement to the measured vertical profiles with the CTD at station 1 (Figures 3 and 4).

Coastal springs were implemented into the model utilizing 13 concentrated water sources along the marina coastline (Figure 3). The source inflow was defined with a constant temperature value of $10^{\circ} \mathrm{C}$ and salinity of 0 PSU. The source inflow dynamics depend on precipitation occurrence in the area (Figure 4). A flow rate of one spring source can be calculated using $Q_{S O U R C E}=k \cdot P$, where $P$ is a value of measured precipitation and $k$ is a proportionality coefficient which depends on precipitation and other geophysical factors like soil type and temperature. For the current examination, only precipitation was taken into consideration to define $k$. Coefficient $k$ is determined through model calibration (Figure 9) 
and it has a different value for the winter and summer period because of mentioned climatological conditions. Exponential correlation was determined between precipitation $P$ and coefficient $k$ with the $R^{2}=0.7$ for winter and $R^{2}=0.85$ for the summer period (Figure 9). Each day $25 \%$ of the total water volume created by precipitation was pushed into the domain through the sources at the seawall. In the course of 4 days, the source provided freshwater into the basin after which the freshwater sources subsided.

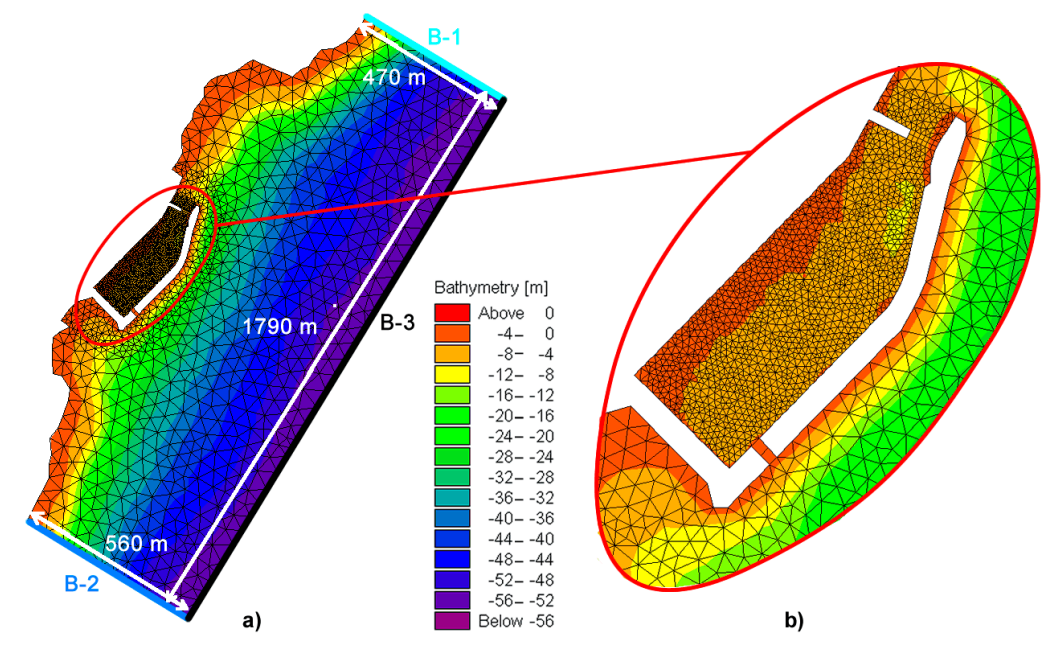

Figure 8. (a) Computational domain used for simulations (discretization with triangular cells); (b) a close-up view of the marina domain.

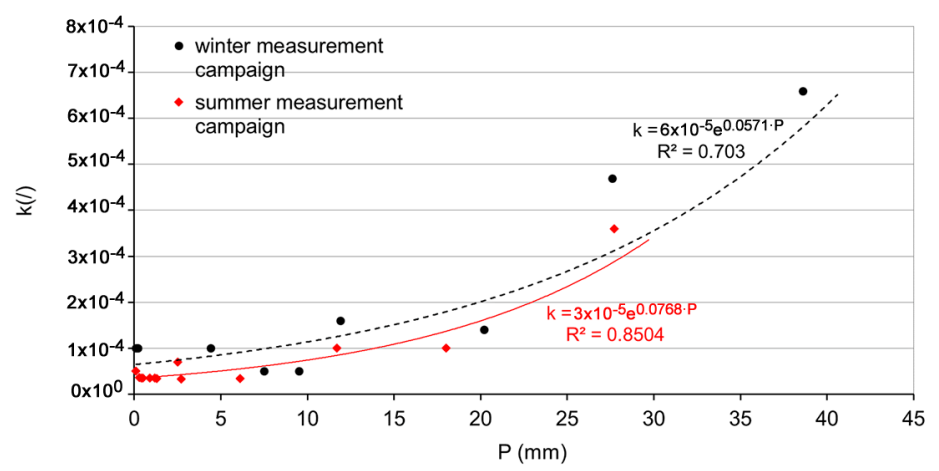

Figure 9. Correlation between the proportionality coefficient $k$ and precipitation $P(\mathrm{~mm})$ used for source inflow rate calculation.

The pipe culvert is implemented in the model as an explicit external routine based upon the difference of sea surface levels between the leeward and seaward side of the breakwater at the culvert position. The culvert is defined in the model as a connected sink-source function inside the domain. Depending on the sea surface difference, the function employs the free surface flow or pressurized flow through the culvert, utilizing the Manning equation in both cases (Manning coefficient $n=0.013 \mathrm{~s} / \mathrm{m}^{1 / 3}$ ). The head loss factors determine the energy (Head) loss over the culvert. The total head loss $\Delta H$ trough culvert is given by:

$$
\begin{gathered}
\Delta H_{\text {loss }}=\frac{Q^{2}}{2 g}\left(\frac{\zeta_{1}}{A_{s 1}^{2}}+\frac{\zeta_{f}+\zeta_{b}}{A_{s}^{2}}+\frac{\zeta_{2}}{A_{s 2}^{2}}\right) \\
\zeta_{1}=\zeta_{\text {IN }}\left(1-\frac{A_{s}}{A_{1}}\right) \quad \zeta_{2}=\zeta_{\text {OUT }}\left(1-\frac{A_{s}}{A_{2}}\right)^{2} \zeta_{f}=\frac{2 g L n^{2}}{R^{4 / 3}}
\end{gathered}
$$


where $Q$ is discharge, $\zeta_{1}$ is the entrance or contraction loss, $\zeta_{2}$ is the outlet or expansion loss, $\zeta_{f}$ is the friction loss calculated using Manning equation, $\zeta_{b}$ is the bend loss coefficient. The suffix ' 1 ' and ' 2 ' represent the area on the inflow and outflow side of the structure respectively, and ' $s$ ' the area in the structure itself [28]. Each head loss factor is defined by a suffix where ' + ' indicates positive flow direction and the suffix ' - ' indicates negative flow direction [28]. The inflow and outflow (positive and negative) head loss factors are constant during a simulation (positive inflow coefficient: $\zeta_{\mathrm{IN}}{ }^{+}=0.9$, negative inflow coefficients: $\zeta_{I_{N}}{ }^{-}=0.5$, positive outflow and negative coefficients $\zeta_{\mathrm{OuT}}{ }^{+}=1.0$, $\zeta_{\text {ouT }}{ }^{-}=1.0$ ). In the wave situations (Tables 2 and 3 ) the head loss factor was variable. The head loss factor values were adopted according to the integrated culvert discharge measured by the PCM device during each wave situation. The head loss factors were varied until the similarity between integrated measured and modelled discharges through the culvert were obtained for each wave situation.

\subsection{Sea Circulation Model Results}

Numerical analyses of sea currents and water mass exchange between the marina basin and the surrounding sea were carried out. A comparison of the measured and modeled hourly averaged current velocities at the position ADCP 1 (Figure 3) is shown in Figures 10 and 11. To evaluate the model performances normalized root-mean-square error (NRMSE) [35] and Nash-Sutcliffe efficiency index (NSE) [36] of the measured and modelled velocity values were used (Table 4). The value of perfect fit for NRMSE is 0 and for NSE is 1 [35]. Obtained values for NRMSE and NSE indicate better resemblance between measured and modelled velocities for the summer than for the winter period. In the summer months, there were less intense transitional conditions of the atmosphere, especially the wind, during which the greater discrepancy between measured and modeled velocities is noticed.

Baroclinic flow is recognized in the marina entrance area. NW, NE and E winds caused the surface layer inflow, while winds of S, SW and W direction caused surface layer outflow. Figure 12 shows the hourly averaged current fields in characteristic situations during the occurrence of baroclinic compensation currents. $\mathrm{N}$ and SE winds coincide with the rainfall occurrence and the coastal spring activation. In the winter period two similar situations were detected during which $\mathrm{N}$ wind, contrary to expected, caused outflow current in the marina entrance area (on 7 March 15:00-21:00 $\mathrm{h}$ with average speed of $3.97 \mathrm{~m} / \mathrm{s}$, and on 8 March 5:00 h-8:00 h with average speed of $5 \mathrm{~m} / \mathrm{s}$ ). In the mentioned situations coastal springs were active and had more influence on surface layer flow than wind had.
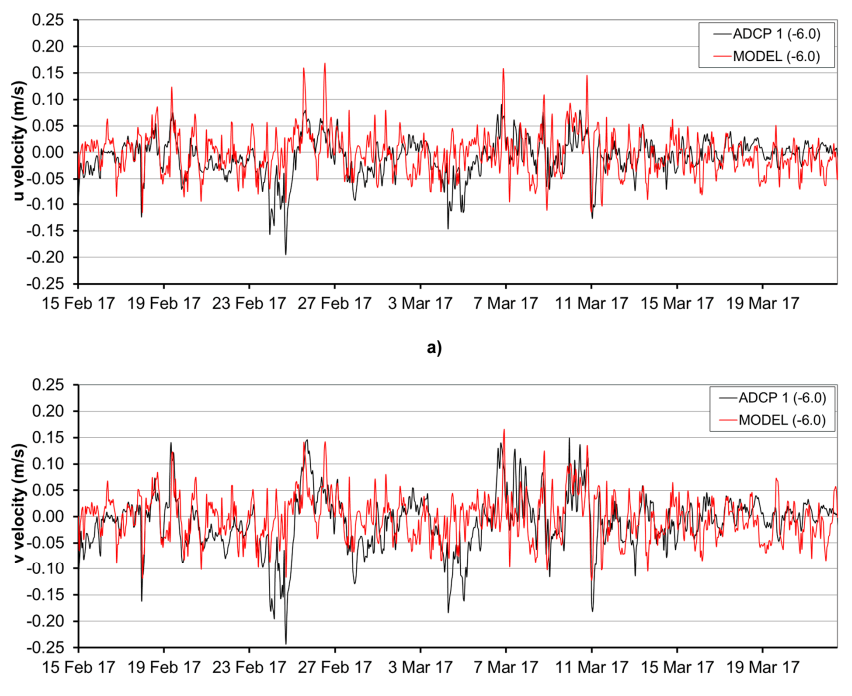

b)

Figure 10. Comparison of measured and modeled hourly averaged (a) $u$ velocity component and (b) $v$ velocity component at a depth of $-6 \mathrm{~m}$ at the position of ADCP 1 for the winter period. 
Table 4. Normalized root-mean-square error (NRMSE) and Nash-Sutcliffe efficiency index of the measured and modelled velocity values.

\begin{tabular}{ccccc}
\hline \multicolumn{3}{c}{ ADCP-1 (-6 m) } \\
\hline & Winter & \multicolumn{2}{c}{ Summer } \\
\hline & $\boldsymbol{u}$ & $\boldsymbol{v}$ & $\boldsymbol{u}$ & $\boldsymbol{v}$ \\
\hline NRMSE & 1.10 & 0.98 & 0.94 & 0.86 \\
NSE & -0.36 & -0.01 & 0.12 & 0.25 \\
\hline
\end{tabular}
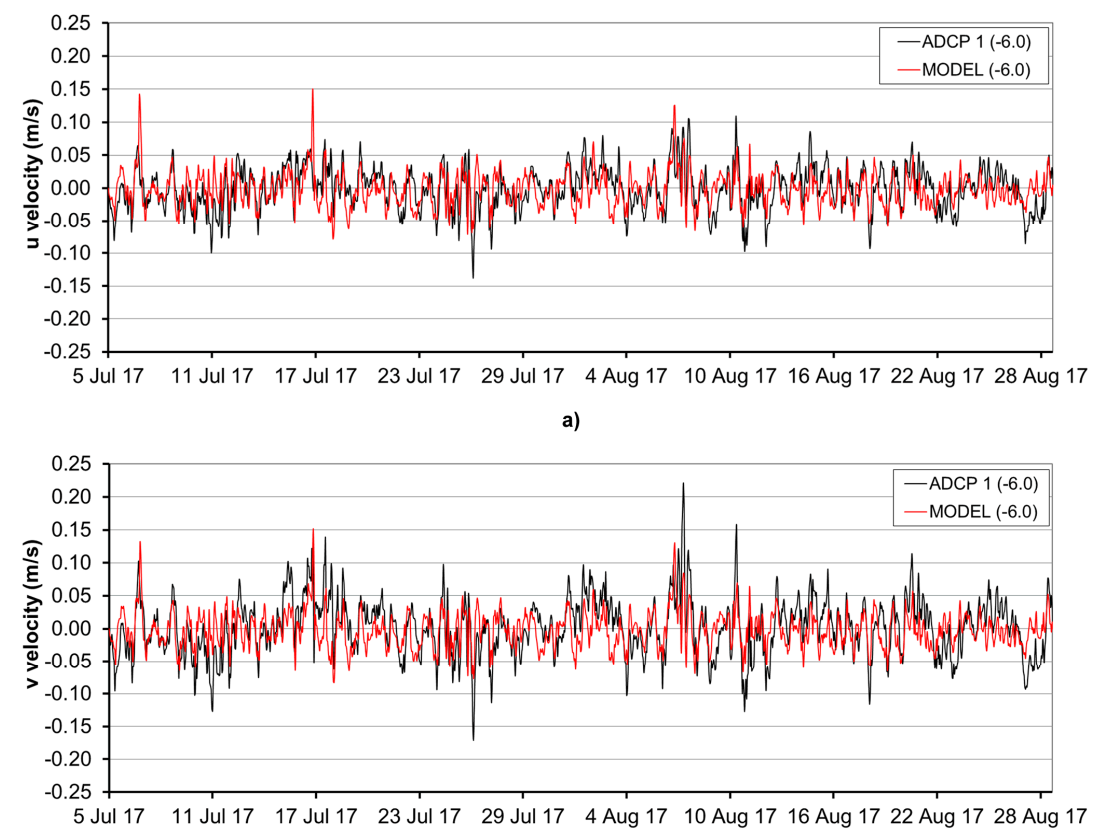

b)

Figure 11. Comparison of measured and modeled hourly averaged (a) $u$ velocity component and (b) $v$ velocity component at a depth of $-6 \mathrm{~m}$ at the position of ADCP 1 for the summer period.

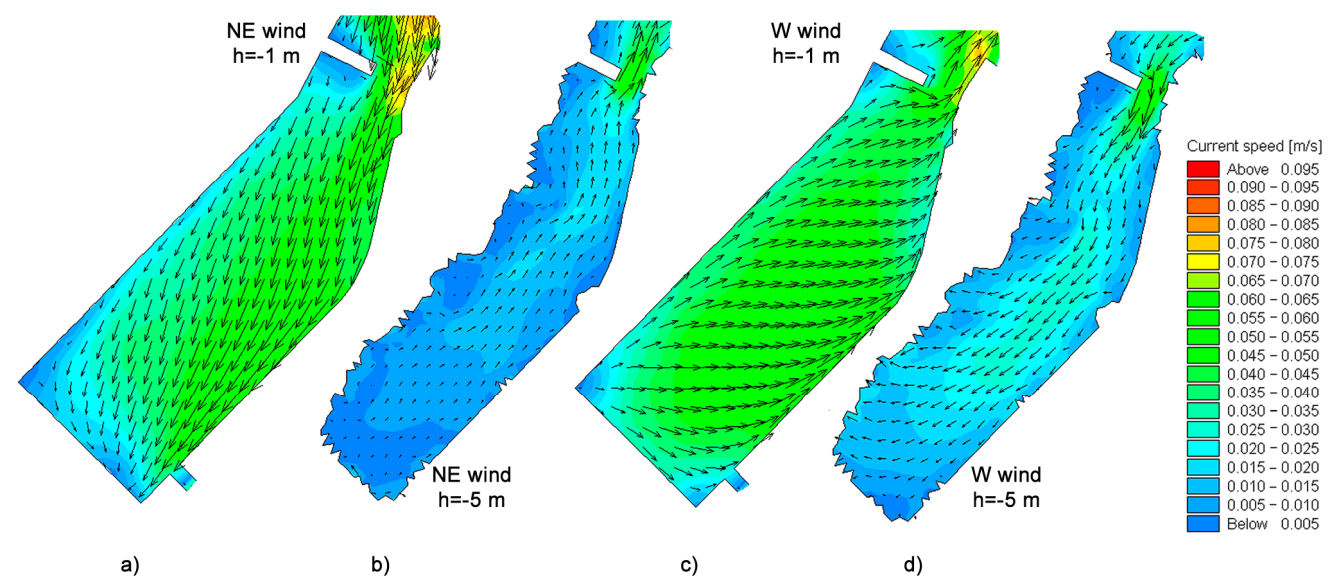

Figure 12. Hourly averaged current fields in the characteristic situations during an occurrence of barocline compensation currents in the area of the marina entrance, induced by $(\mathbf{a}, \mathbf{b}) \mathrm{NE}$ wind episode on 7 March 2017, 23:00 h, at a depth (a) $h=-1 \mathrm{~m}$ and (b) $\mathrm{h}=-5 \mathrm{~m} ;(\mathbf{c}, \mathbf{d}) \mathrm{W}$ wind episode on 10 August, 17:00 $\mathrm{h}$ at a depth (c) $\mathrm{h}=-1 \mathrm{~m}$ and $(\mathbf{b}) \mathrm{h}=-5 \mathrm{~m}$. 
The surface mixed-layer in a stratified water body is defined as that part of a water column which is directly influenced by momentum and turbulence introduced by a wind surface stress [37]. The spatial distribution of turbulent kinetic energy (TKE) (Figure 13) indicates the location of its production and diffuse propagation. The winds of N, SW and NE direction had the most intensive impact on the diffusion of TKE down through the water column (Figure 13). The mixed-layer deepens, and a homogenous density distribution is established.
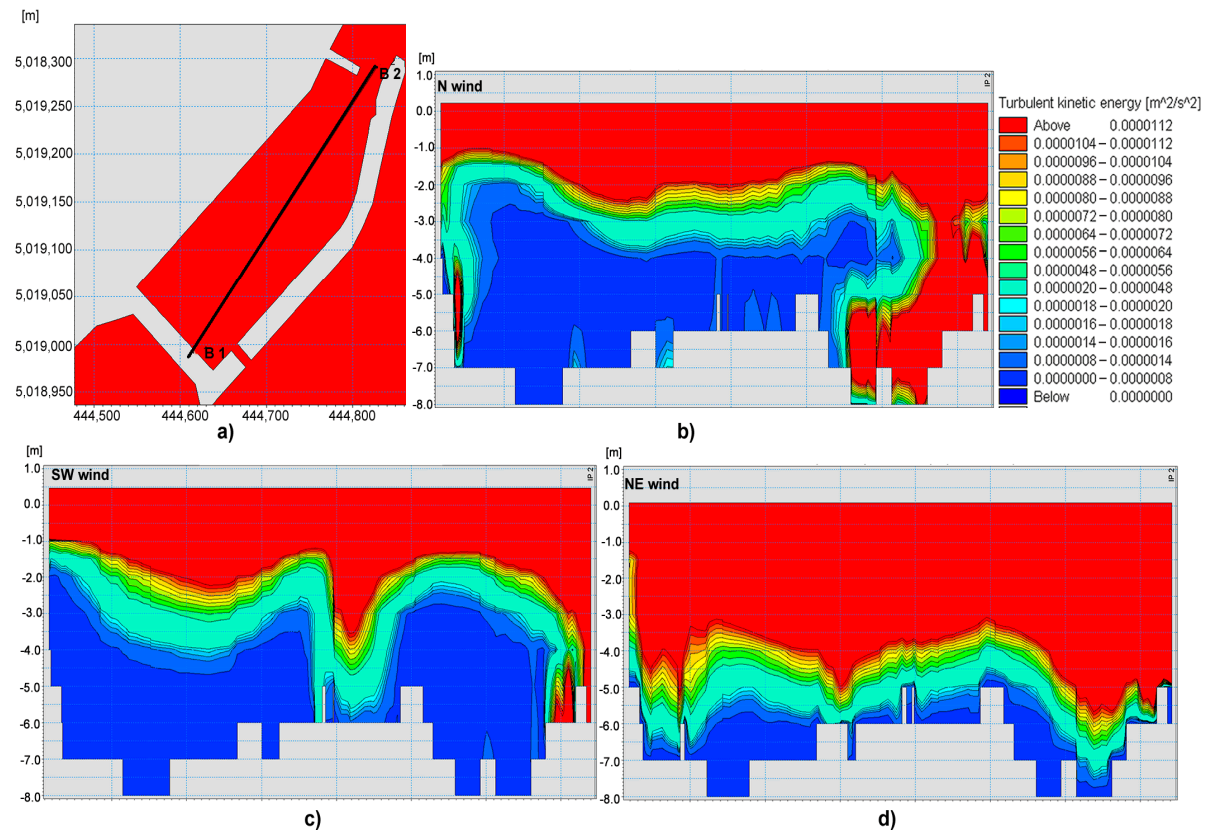

Figure 13. Turbulent kinetic energy field for the wind of $4.5 \mathrm{~m} / \mathrm{s}$ speed trough vertical cross-section B1-B2: (a) the cross-section B1-B2 position; (b) TKE on 10th of March, 19:00 h for N wind; (c) TKE on 4th of March 22:00 h for SW wind; (d) TKE on 14th of July 10:00 h for NE wind.

Oakey and Elliott [38] reported a relationship between the dissipation rate of mechanical energy in the surface mixed-layer and the wind energy. The correlation between the energy dissipation rate and wind forcing showed a linear relationship between $\varepsilon_{I N T}$ and $\left(U_{10}\right)^{3}$. Here, $\varepsilon_{I N T}$ is an average value of the dissipation rate integrated over the depth, and $U_{10}$ is an average wind speed measured at $10 \mathrm{~m}$ above the water surface. Figure 14 shows the mentioned linear relationship for the winds of $\mathrm{N}$, $\mathrm{NE}$ and SW directions with the $R^{2}=0.99$ for all three directions.

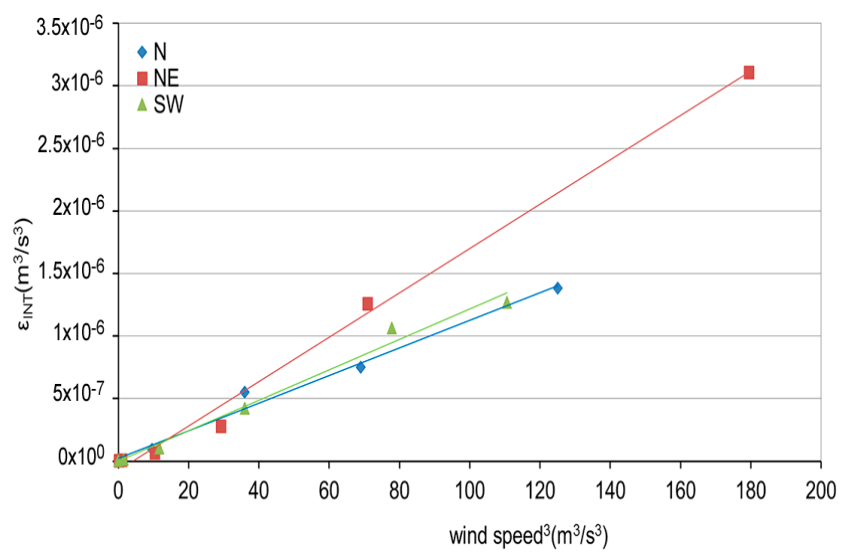

Figure 14. The integrated dissipation of turbulent kinetic energy through the vertical profile in the point of the marina centroid versus the cube of the wind speed for the N, NE and SW wind direction. 
The goal of the model calibration was to obtain the best similarity between the integrated discharge measured by PCM and modelled through one culvert pipe. Figure 15 shows the results of the measured and modelled integrated discharge through one culvert pipe.
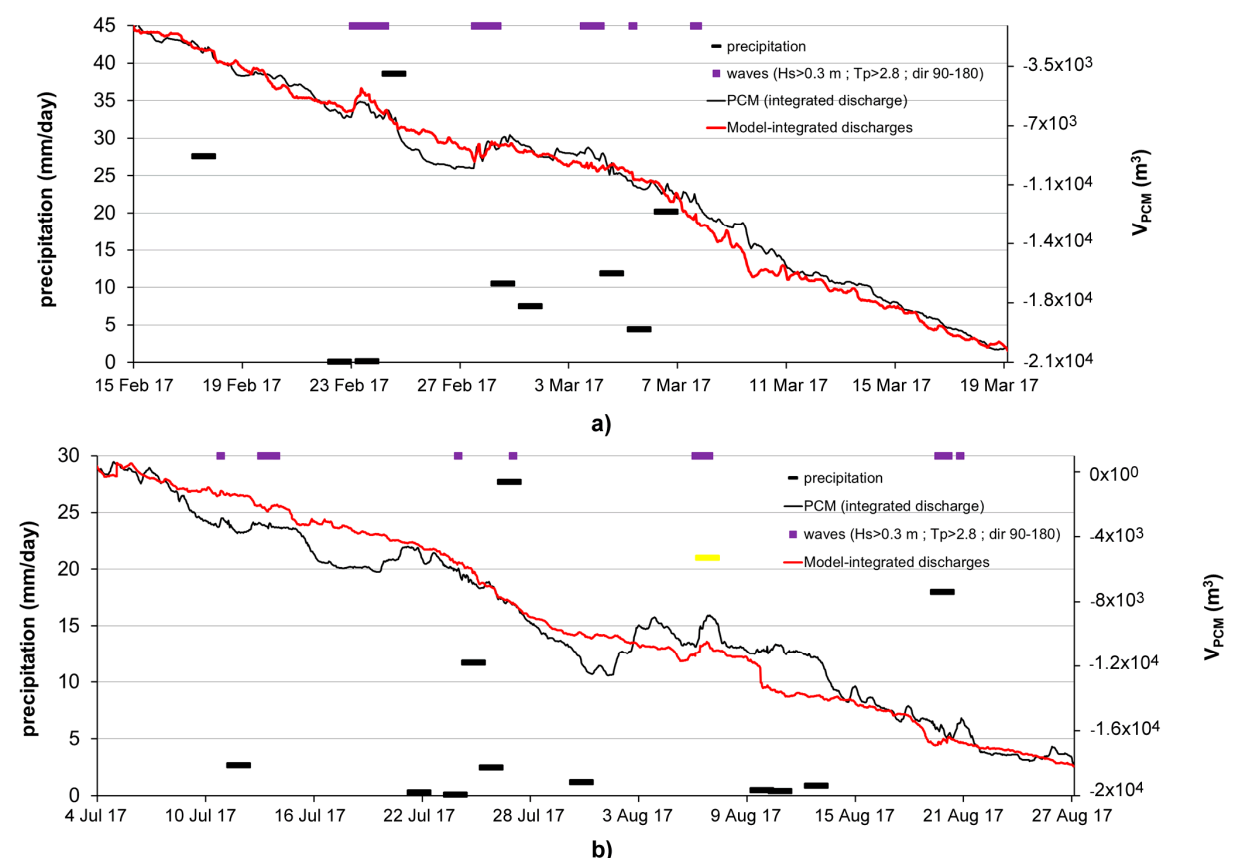

Figure 15. Comparison of the measured integrated discharge and modeled integrated discharge for (a) winter measurement period and (b) summer measurement period.

In the winter measurement campaign, the integrated measured discharge through the one culvert and obtained from the model shows better agreement than in the summer period. The results of the model integrated discharges include the contribution of waves and coastal springs along the marina coastline (as explained in Section 2). The coastal springs flow rate was calculated according to curves in Figure 9. In the winter period, all measured precipitation was taken into account for source inflow calculation. In the summer period, it was assumed that the rain on 7 August (yellow bar in Figure 15) did not activate springs in the marina and there was no noticeable culvert outflow measured by the PCM device. As mentioned before, in the summer period during the low wind speeds of NW direction, significant culvert inflow due to an unknown flow generator is recorded and cannot be obtained by model.

\subsection{Wave Generation Model Setup}

A regional model encompassing the entire Adriatic Sea was established in previous research in order to validate the numerical wave generation model. The Figure 16 shows the domain included within the numerical model and how the domain was meshed using finite volumes. The distance between the numerical nodes is ranging from $10 \mathrm{~km}$ in the deep-water area to $250 \mathrm{~m}$ in the shallow water.

The spectral numerical model Mike 21/SW [39,40] was used for the numerical analysis with which it is possible to simulate the generation, deformation and attenuation of gravitational wind waves in open-sea and coastal areas. The model computes the evolution of wave action density by solving the action balance equation [41,42]. To discretize the wave spectra in the frequency domain, a logarithmic scale was employed with a minimum frequency of $0.08 \mathrm{~Hz}$ (wave period $12.5 \mathrm{~s}$ ) up to a maximum frequency of $0.95 \mathrm{~Hz}$ (wave period $1.05 \mathrm{~s}$ ), with 28 discrete steps. The model applies the phenomena of wave generation due to wind action, nonlinear wave interaction, refraction as 
well as the dissipative process caused by surface white-capping. The multi sequential Euler explicit method was used for the discretization of the temporal term and the 'upwind' numerical scheme for the convective flux term.

Initial condition (15 February 2017) is defined with zero wave spectra, meaning the absence of initial wave movement in the modeled area. During the whole analyzed period (15 February 2017 to 23 March 2017) the regional model was forced using wind fields from the atmospheric model Aladin-HR with spatial resolution from $4 \mathrm{~km}$ and time resolution from $3 \mathrm{~h}[43,44]$.

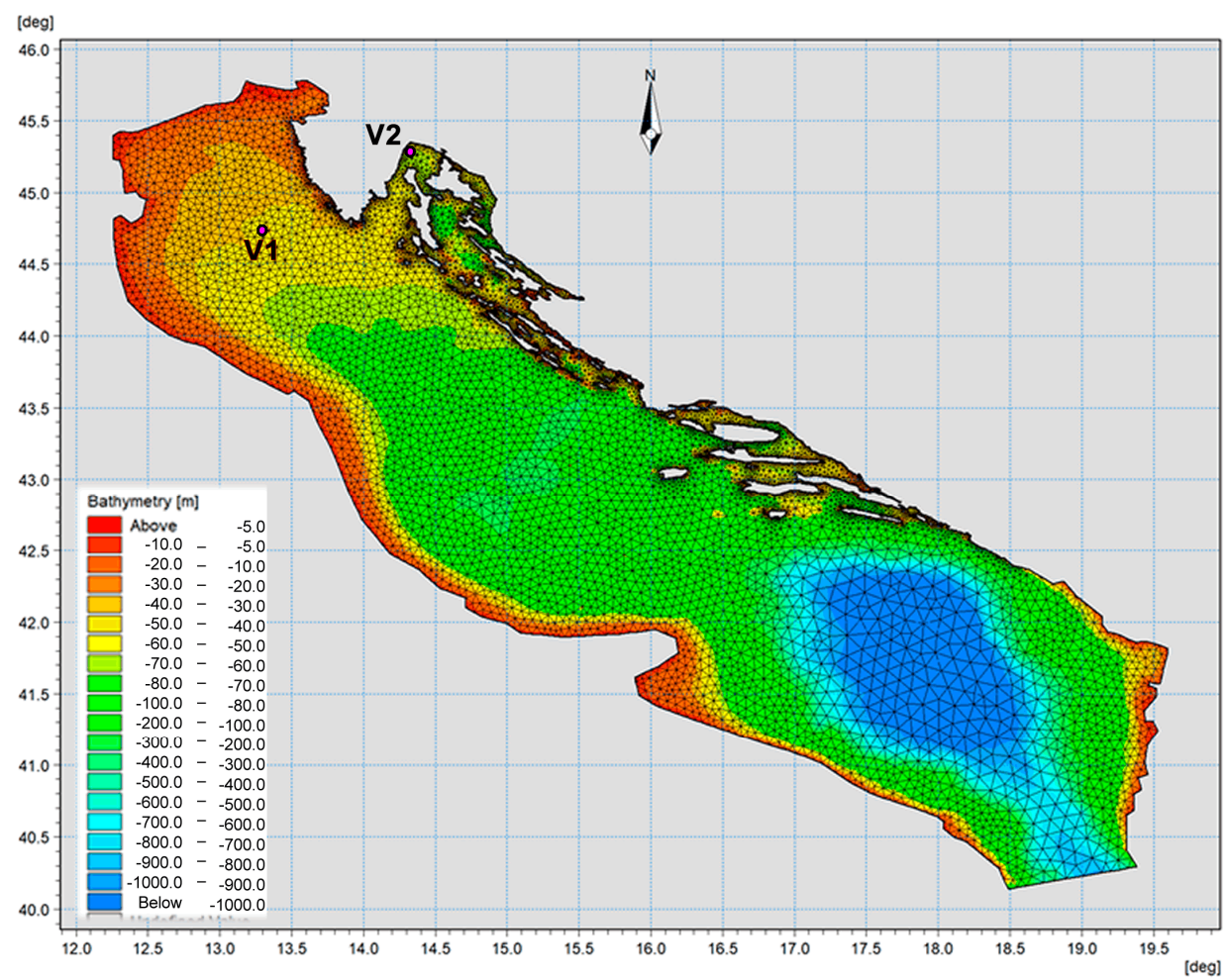

Figure 16. Model domain spatial discretization with unstructured finite volume grid on bathymetric background and locations of wave rider stations $\mathrm{V} 1\left(\phi=44^{\circ} 44.57^{\prime} \mathrm{N}, \lambda=13^{\circ} 17.98^{\prime} \mathrm{E}\right)$ and $\mathrm{V} 2$ $\left(\phi=45^{\circ} 19.37^{\prime} \mathrm{N}, \lambda=14^{\circ} 18.7^{\prime} \mathrm{E}\right)$.

Two sources were used for calibration of the wave generation model. The first was measurements from the wave rider station V1 situated in the northern Adriatic open-sea area (see Figure 16 $\left(\phi=44^{\circ} 44.57^{\prime} \mathrm{N}, \lambda=13^{\circ} 17.98^{\prime} \mathrm{E}\right)$. Figure 17 shows the comparison of measured and modelled significant wave heights at the wave recording station during the period from 15 November 2007 to 15 November 2008. Statistical errors of modelled values for half-hourly average wave heights at the wave recording station in relation to measured values for the simulation period have the following feature(s): average error $\mathrm{AE}=0.064$; root mean square error $\mathrm{RMSE}=0.0038$. The second source on wind-wave data represents measurements at wave rider site V2 in front of the main breakwater in Rijeka Harbor (see Figure 16, station V2). Figure 18 shows the relationship between measured significant wave heights $H_{S}$ and the peak period $T_{P}$ (wave rider site V2) against measured wind speed $V_{\text {wind }}$, for wind activity from SSE direction.

After the calibration process of the wave generation model was done, it was used for the wave generation during the winter and summer period along which the culvert discharge was measured in the marina Opatija. Figure 19 shows the values of the significant wave heights at station 1 (Figure 3).

The differences of measured (station 1) and modelled wave height have been analyzed with a normalized root mean square error (NRMSE) approach [42], gaining the NRMSE $=0.63$ for winter measurement period and NRMSE $=0.51$ for summer measurement period. 


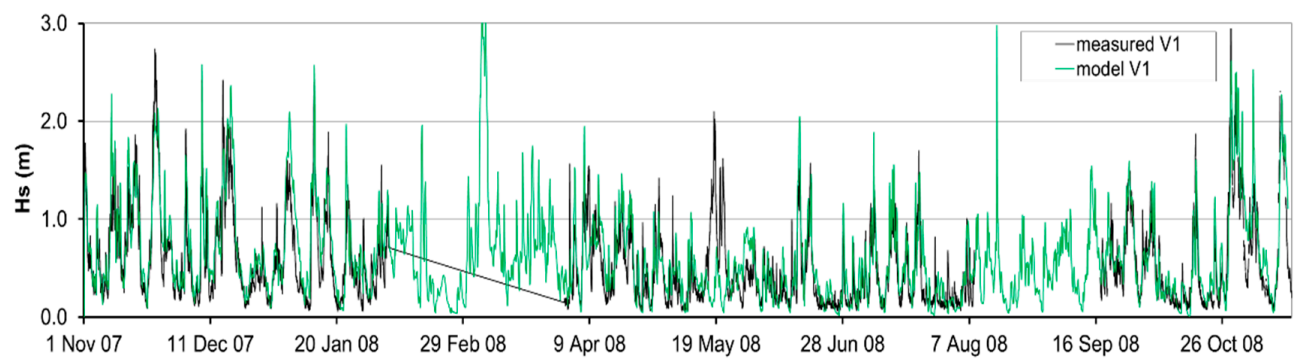

Figure 17. Comparison of measured and modelled time series of significant wave heights $H$ s at wave measurement station V1 in the northern Adriatic open-sea area $\left(\phi=44^{\circ} 44.57^{\prime} \mathrm{N}, \lambda=13^{\circ} 17.98^{\prime} \mathrm{E}\right)$.

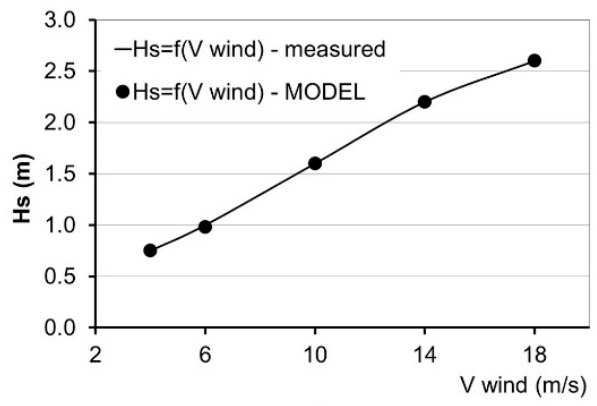

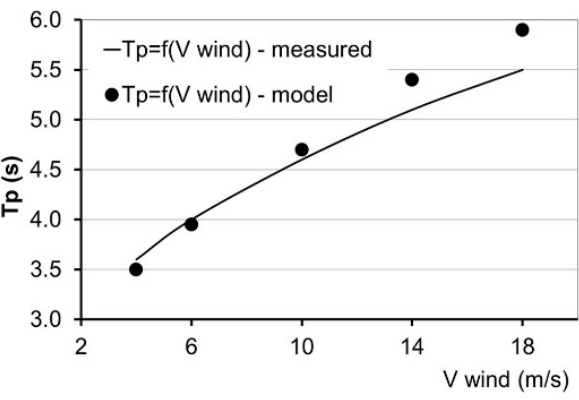

b)

Figure 18. Relationship of measured and modelled (a) significant wave heights $H_{S}$ and (b) peak period $T_{P}$ against measured wind speed $V_{\text {wind }}$, under the action of wind from SSE direction in the course of $12 \mathrm{~h}$ (recording obtained from measurement at wave rider site in front of the main breakwater in Rijeka Harbour).

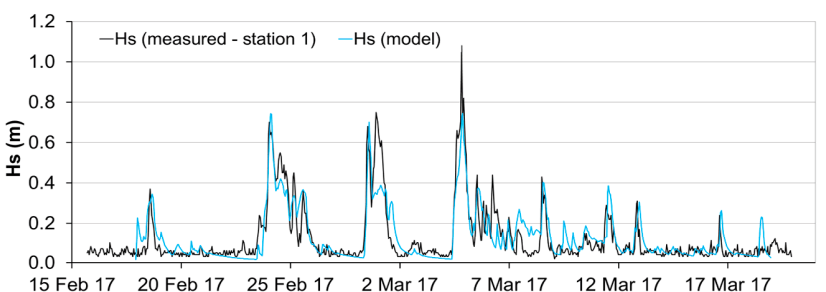

a)

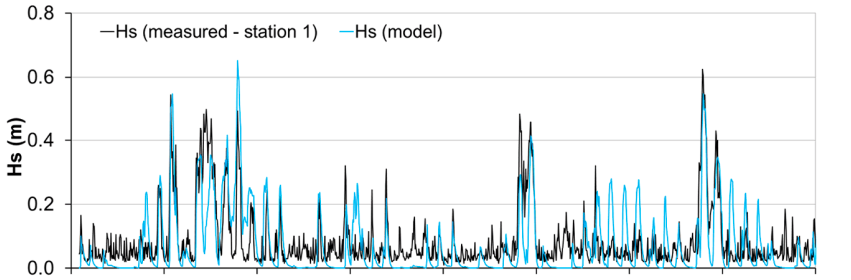

4 Jul $17 \quad 11$ Jul $17 \quad 18$ Jul 1725 Jul 17 A Aug 178 Aug 1715 Aug 1722 Aug 1729 Aug 17

d)

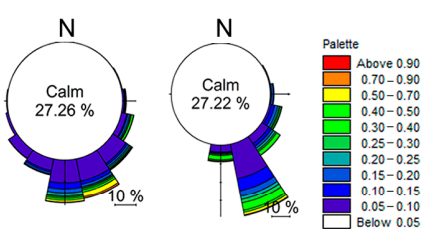

b)

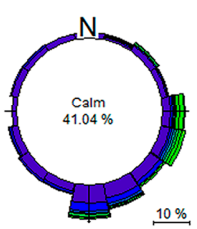

e) c)

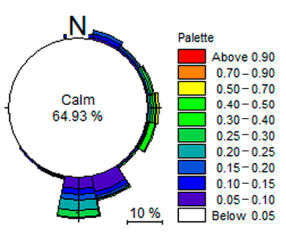

f)

Figure 19. Comparison of measured and modelled time series of significant wave heights $H_{S}$ at measurement station 1 for the (a) winter and (d) summer measurement periods with corresponding wave roses from $(\mathbf{b}, \mathbf{e})$ measured and $(\mathbf{c}, \mathbf{f})$ modelled data.

Figure 19 and the data presented in Tables 2 and 3 clarify that there was no strong wave activity during the analysed periods (15 February-20 March and 4 July-29 August). The field of significant wave heights in the situation of a Sirocco wind on 4 March 2017 20:00 h is shown in Figure 20. In the period 15 February 2017 to 23 March 2017 the value of recorded maximum significant wave height is $H_{S}=1.08 \mathrm{~m}$ and the modelled value is $H_{S}=0.73 \mathrm{~m}$. 


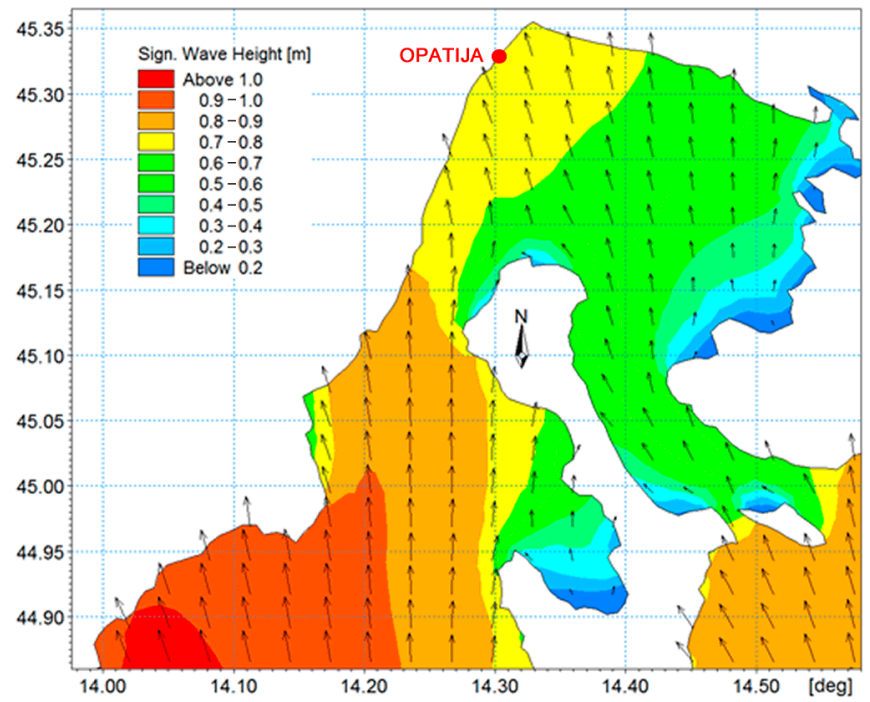

Figure 20. Field of significant wave heights for the situation of strong Sirocco wind (4 March 2017).

\subsection{Wave Generation Model Results}

Table 5 shows an average number of hours per year (1992-2001) in which wind waves are characterized by: $H_{S}>0.3 \mathrm{~m}$ and $T_{P}>2.8 \mathrm{~s}$ and incident wave direction in the band from $90^{\circ}$ (E) to $180^{\circ}$ (S). Also, the average number of hours with recognised adopted wave situations during the winter and summer period are shown, if the months from May to October are assumed as the summer period and the rest as the winter period. An average amount of hours with significant wave situations in the course of one year is $801 \mathrm{~h}$, which is $9 \%$ of the year (approximately one month-32 days). According to the Tables 3 and 4 , the total volume of the sea exchange (through one culvert pipe) caused by wave action is $13 \%$ of the total seawater exchange in 10 years (1992-2001). The mentioned percentages show that even small waves have a significant impact on the sea exchange through the flushing culverts.

Table 5. An average number of hours per year (and per season) with recognised wind waves assuming criteria: $H_{S}>0.3 \mathrm{~m}$ and $T_{P}>2.8 \mathrm{~s}$ and incident wave direction in the band from $90^{\circ}$ (E) to $180^{\circ}$ (S) at the location of the marina Opatija.

\begin{tabular}{cccc}
\hline & $\boldsymbol{H}_{\boldsymbol{S}} \mathbf{>} \mathbf{0 . 3} \mathbf{~ m} \boldsymbol{T}_{\boldsymbol{P}} \mathbf{>} \mathbf{2 . 8} \mathbf{s}, \mathbf{d i r} \mathbf{9 0 - \mathbf { 1 8 0 } ^ { \circ }}$ & Winter (November-April) & Summer (May-October) \\
\hline Year & Total Duration (h) & $\mathbf{( h )}$ & (h) \\
\hline 1992 & 820 & 450 & 370 \\
1993 & 752 & 263 & 489 \\
1994 & 820 & 475 & 345 \\
1995 & 765 & 380 & 385 \\
1996 & 760 & 476 & 284 \\
1997 & 695 & 311 & 384 \\
1998 & 675 & 411 & 264 \\
1999 & 760 & 476 & 284 \\
2000 & 838 & 411 & 427 \\
2001 & 1128 & 712 & 416 \\
\hline average & 801 & 437 & 365 \\
\hline
\end{tabular}

\section{Discussion}

\subsection{Field Measurements and Results from the Referenced Physical Model}

In previous research $[25,26]$, the optimum vertical placement of a culvert in regard to the mean sea level was studied in order to achieve the maximum flushing using the influence of waves. A series of 
tests on a physical model of breakwater in a wave flume were conducted with the goal of investigating the effect of irregular wave fields on velocities inside them.

Concerning the fully submerged culvert, the velocity generally fluctuated around $0 \mathrm{~m} / \mathrm{s}$ throughout the testing period. The absolute values of the mean velocities were mainly below $0.1 \mathrm{~m} / \mathrm{s}$ in more than $90 \%$ of the test cases, which suggests a wave damping effect of a fully submerged culvert regarding velocity values. The stated hindering effect was only detected if the water level was at the top of the culvert, irrespective of the incident wave field in approaching the breakwater. On the other hand, if the culvert was partially submerged in water, the mean velocity had a substantially higher value that extends from $0 \mathrm{~m} / \mathrm{s}$ to $1 \mathrm{~m} / \mathrm{s}$. The velocity of the water oscillates predictably in accordance with the sinusoidal function. In conclusion, the velocity magnitudes recorded at the end of the culvert are substantially lower in the case of a fully submerged flushing culvert than in the case of a partially submerged.

The influence of several wave parameters and geometrical culvert features to the velocity at the culvert exit was studied. The authors provided the following empirical expression to evaluate the culvert velocity [25]:

$$
v_{p}=\sqrt{g d} \cdot\left(0.097 \cdot\left(\frac{H \cdot L}{d \cdot L_{c} \cdot w^{4}}\right)^{0.34}-0.11\right)
$$

where: $v_{p}$ is the velocity at the exit out of the culvert, $g$ is the gravitational constant, $d$ is the culvert diameter, $H$ and $L$ correspond to significant wave height and peak wave length respectively, $L_{\mathcal{C}}$ is the culvert length, and $w$ is the submergence coefficient which is defined as the ratio of water level measured from the bottom of the culvert and culvert diameter, consequently it is a dimensionless value.

The proposed Equation (3) is now further utilized for the prediction of the average flow through the culvert assuming the following relations: $Q_{M}=v_{p} \cdot A$, where a uniform velocity distribution is assumed across the whole wetted cross-section. In accordance to the Froude similarity criterion and length ratio of $\alpha=10$, discharge could be defined in the prototype scale $Q_{P}$ using the following ratio factor: $Q_{R}=Q_{P} / Q_{M}=\alpha^{5 / 2}=316.2$ (Table 6). Calculated values of $Q_{P}$ (Table 6) indicate the important contribution of waves on seawater exchange through the flushing culvert. Discharges $Q_{P}$ are evaluated primarily for the incident waves that are perpendicular to the breakwater.

Table 6. Field measured discharge values through the flushing culvert and predicted discharge values according to the proposed Equation (1), in regards to the present wave parameters.

\begin{tabular}{cccccccccc}
\hline Date & $\begin{array}{c}H_{S-M} \\
{[\mathrm{~m}]}\end{array}$ & $\begin{array}{c}T_{P-M} \\
{[\mathbf{s}]}\end{array}$ & $\begin{array}{c}L_{P-M} \\
{[\mathrm{~m}]}\end{array}$ & $\begin{array}{c}H_{S-P} \\
{[\mathrm{~m}]}\end{array}$ & $\begin{array}{c}T_{P-P} \\
{[\mathbf{s}]}\end{array}$ & $\begin{array}{c}L_{P-P} \\
{[\mathrm{~m}]}\end{array}$ & $\begin{array}{c}S E \\
{[\mathrm{~m}]}\end{array}$ & $\begin{array}{c}Q_{P} \\
{\left[\mathrm{~m}^{3} / \mathbf{s}\right]}\end{array}$ & $\begin{array}{c}Q_{P-P C M} \\
{\left[\mathrm{~m}^{3} / \mathbf{s}\right]}\end{array}$ \\
\hline 28 February 2017 & 0.06 & 0.98 & 1.50 & 0.60 & 3.10 & 15.0 & -0.15 & 0.04 & 0.08 \\
4 March 2017 & 0.06 & 0.98 & 1.50 & 0.60 & 3.10 & 15.0 & 0.17 & -0.07 & -0.02 \\
\hline
\end{tabular}

The prototype discharge values $Q_{P}$, evaluated from the results of the physical model, are compared to the discharge values at ACI marina Opatija measured with the PCM device (Table 6). For easier comparison, situations with a similar wave field were considered to evaluate the influence of the culvert submergence. The corresponding significant wave height matches $0.6 \mathrm{~m}$, and wave length equals $15 \mathrm{~m}$. The surface elevation (SE) changed between the observed situations.

As observed by the field measurements, the higher the water elevation is above the top of the culvert the smaller the flow rates are. Sometimes flow rate values could also be negative, indicating that water is exiting the marina through the culvert. As the sea level decreases, the flow rate becomes more positive which is observed in both field measurements and laboratory experiments. This could be viewed on the 28 February where the largest inflow is observed $\left(0.08 \mathrm{~m}^{3} / \mathrm{s}\right)$, and also the largest inflow is evaluated using Equation (3) $\left(0.04 \mathrm{~m}^{3} / \mathrm{s}\right)$. On the 4 March, the outflow was observed $\left(-0.02 \mathrm{~m}^{3} / \mathrm{s}\right)$ while the culvert was submerged $(\mathrm{SE}=0.17 \mathrm{~m})$ and the outflow was evaluated $\left(-0.07 \mathrm{~m}^{3} / \mathrm{s}\right)$ using Equation (3). The difference between the observed and evaluated flow (using Equation (3)) is probably 
due to incident wave angle, which is always perpendicular to the breakwater during the laboratory tests, which is not the case during the field measurements. An additional influence that could cause a flow value discrepancy is the fact that the measured flow rates in the marina Opatija were affected by wind, tidal oscillations, density gradients and other atmospheric conditions. Due to discrepancies, the proposed equation (obtained by laboratory measurements) may serve as the first approximation in the engineering assessment of the sea exchange through the culvert pipes.

The results displayed in Figure 21 also confirm the influence of the surface elevation on the flow rate through the flushing culvert. With the decline of the surface elevation below the top of the culvert, the flow rate tends to the inward direction. On the other hand, the rising of the surface elevation above the top of the culvert produces outflow from the marina.
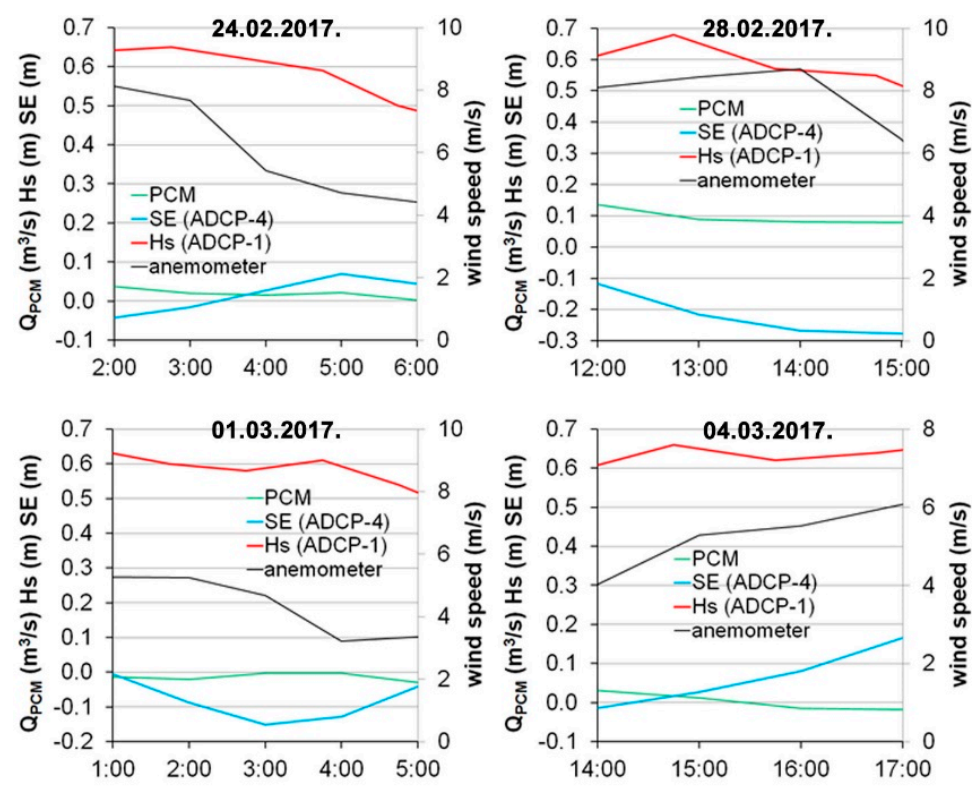

Figure 21. Hourly averaged field measured values of significant wave height $\left(H_{S}\right)$, surface elevation (SE), flushing culvert discharge measured with the PCM and wind velocity, during situations where the wave parameters were approximately equivalent.

\subsection{Flushing Culverts Position}

The change in the flushing efficiency by varying the culvert position, when the waves were not taken into consideration, is analyzed in the previous research [19]. The culvert's position, opposite to the main harbor entrance, was recognized as optimal for the marina flushing. In the marina Opatija, where culverts are positioned following the main direction of the incident wave propagation, coastal springs and wind waves are recognized as flow generators affecting the marina flushing. Statistical values regarding the flow measured inside the flushing culvert are shown in Table 7 . The entire sea exchange is calculated as the sum of absolute volume passing through the culvert and the marina entrance cross section $\left(V_{a b s}=\left|V_{1 \text {-culvert }}\right|+\left|V_{\text {entrance }}\right|\right)$. The absolute volume passing through the marina entrance cross section is obtained by the model (winter: $\left|V_{\text {entrance }}\right|=1,567,178 \mathrm{~m}^{3}$, summer: $\left.\left|V_{\text {entrance }}\right|=2,576,703 \mathrm{~m}^{3}\right)$. The absolute amount of the sea exchange through the one flushing culvert is $3 \%$ of total sea exchange for the winter period and $2 \%$ for the summer period (Table 7 ). The sea exchange caused by the wave action (Tables 1 and 3) over the total absolute volume obtained through the one culvert pipe is $15 \%$ in the winter and $4 \%$ in the summer period. During the winter period, the absolute sum of water passing through the one culvert pipe is $5 \%$ lower if not taking into account the impact of inflow caused by freshwater sources. Mentioned percentages indicate that flows caused by wind waves have more significant impact on the seawater exchange than freshwater sources. The absolute volume of sea exchange through the eight culverts obtained by model $\left(\left|V_{8 \text { culvert }}\right|=341,603 \mathrm{~m}^{3}\right)$ is seven 
times higher compared to the volume through one culvert pipe. The absolute volume of sea exchange through the eight pipes is $18 \%$ of the total sea exchange, which has an important role in the marina water dynamics.

Table 7. Statistical values regarding the flow measured inside the flushing culvert.

\begin{tabular}{ccccccc}
\hline & $\begin{array}{c}\text { Measurement } \\
\text { Duration } T(\mathbf{h})\end{array}$ & $\begin{array}{c}\text { 1 Culvert } \\
\text { Absolute Sum } \\
\left.\left|V_{\mathbf{1 - c u l v e r t}}\right| \mathbf{( m}^{\mathbf{3}}\right)\end{array}$ & $\begin{array}{c}\text { 1 Culvert Mean abs. } \\
\text { Discharge } \\
\left|V_{\mathbf{1 - c u l v e r t}}\right| / \boldsymbol{T}\left(\mathbf{m}^{\mathbf{3}} / \mathbf{h}\right)\end{array}$ & $\begin{array}{c}\text { Wave sit. } \\
\text { Duration } \\
\boldsymbol{T}_{w}(\mathbf{h})\end{array}$ & $\begin{array}{c}\text { Wave sit. } \\
\text { Absolute Sum } \\
\left.\left|V_{\mathbf{1 - w a v e s}}\right| \mathbf{m}^{\mathbf{3}}\right)\end{array}$ & $\begin{array}{c}\text { Wave sit. Mean abs. } \\
\left|V_{\mathbf{1 - w a v e s}}\right| / T_{w}\left(\mathbf{m}^{\mathbf{3}} / \mathbf{h}\right)\end{array}$ \\
\hline Winter & 786 & 50,213 & 64 & 71 & 7406 & 104 \\
Summer & 1340 & 76,966 & 57 & 53 & 3166 & 60 \\
\hline
\end{tabular}

\subsection{Estimation of the Marina Flushing Characteristics}

Adequate flushing time of the marina basin is one of most important measures for the water quality in marinas. The tidal prism analytical model $[38,45]$ is used for predicting the marina flushing time $\left(T_{f}\right)$. Schwartz and Imberger [11] reported the comparison of the tidal prism model with the measured dilution rate. The tidal prism model describes the general water exchange characteristics of a semi-enclosed basin using a simplified analytical model (Equation (4)). The present formulation considers only the tide-induced and freshwater flushing effects:

$$
T_{f}=\frac{V+P}{(1-b) \frac{P}{T}+(1+b) \frac{Q_{R}}{2}}
$$

where: $P$ indicates the tidal prism (in this case: $\left.19,292 \mathrm{~m}^{3}\right), V$ is the mean basin volume $\left(192,925 \mathrm{~m}^{3}\right)$, $T$ is the tidal period $(12 \mathrm{~h}), Q_{R}$ designates the freshwater discharge $\left(0.5 \mathrm{~m}^{3} / \mathrm{h}\right)$, and $b$ is the return flow factor (0.7 according to [16]). Taking into account the mentioned values appropriate for ACI marina Opatija, the flushing time of the marina according to Equation (4) equals 439 h. Furthermore, this value was compared with the flushing time calculated by the use of the established numerical model. The flushing time was evaluated utilizing the CSTR model which considers the time needed for the concentration to fall to $e^{-1}(37 \%)$ as the flushing time of the semi-enclosed basin [45]. A flushing time of $65 \mathrm{~h}$ is calculated by the numerical model utilizing the transport module for the tracer scalar field in conjunction with the calibrated hydrodynamic model, which is significantly lower than the time calculated by the analytical model.

For the studied marina, the calculated $T_{f}$ using the analytical model was seven times higher than that evaluated using the numerical model. Due to this significant discrepancy between the results, it could be concluded that the analytical model does not offer a satisfactory value of marina flushing time. Some other researches also reported discrepancies where the mean flushing times were being overestimated by the analytical model $[11,45]$.

\section{Conclusions}

Water quality of semi-enclosed basins depends on the flushing efficiency. Flushing culverts are the most cost-effective and relatively simple solution to improve the water renewal within an enclosed maritime area. Field measurements were performed inside and in the vicinity of ACI Marina Opatija where eight parallel flushing culverts are embedded in the primary breakwater. The 3D sea circulation and wave generation model were calibrated for the winter and summer measurement period. Flow generators contribution to the flow through the flushing culverts were analyzed.

The incident wind waves approaching the marina in a band from $90^{\circ}(\mathrm{E})$ to $180^{\circ}(\mathrm{S})$ provide the most intense culvert inflow. Even small waves $\left(H_{S} \geq 0.3 \mathrm{~m} ; T_{P} \geq 2.8 \mathrm{~s}\right)$ have a significant impact on the flow through the culverts. The sea exchange caused by the wave action over the total absolute volume obtained through one culvert pipe is $15 \%$ in the winter and $4 \%$ in the summer period. When the observed period is expanded to 10 years, it is concluded that wind waves could produce a considerable volume of the water exchange through the culverts. In relative relation to other flow generators, 
waves caused the $13 \%$ of the total seawater exchange. Coastal springs flow is recognised along the marina coastline after rainfall events and is more dominant in the winter than in the summer period. Their activation effects the culvert outflow and surface layer current. Its absolute volume accounts 5\% of the total absolute volume obtained through the one culvert pipe in the winter period. The results from the physical model indicate that the flow through the culvert pipe depends on the culvert submergence. Field measurement confirmed the influence of the surface elevation on the flow rate through the culvert pipe. The higher the water elevation is above the top of the culvert, the smaller the flow rates are.

In conclusion, to achieve more efficient seawater exchange in the marina basin, it is suggested to position flushing culvert axis at the mean sea level following the main direction of the incident wave propagation.

Author Contributions: G.L. and D.C. conceived and designed the experiments; D.B., D.C. and I.B. performed the experiments; all authors analyzed the data; D.B. and D.C. contributed analysis tools; all authors wrote the paper.

Funding: This research has been supported by the Croatian Science Foundation under the Project number UIP-2014-09-6774.

Conflicts of Interest: The authors declare no conflict of interest.

\section{References}

1. Airoldi, L.; Beck, M.W. Loss, Status and Trends Forcoastal Marine Habitats of Europe. Oceanogr. Mar. Biol. 2007, 45, 345-405.

2. United Nations, Department of Economic and Social Affairs, Population Division. World Population Prospects the 2017 Revision Key Findings and Advance Tables; United Nations: New York, NY, USA, 2017; Volume 2017, pp. 1-46.

3. Di Franco, A.; Graziano, M.; Franzitta, G.; Felline, S.; Chemello, R.; Milazzo, M. Do Small Marinas Drive Habitat Specific Impacts? A Case Study from Mediterranean Sea. Mar. Pollut. Bull. 2011, 62, 926-933. [CrossRef] [PubMed]

4. Valdor, P.F.; Gómez, A.G.; Puente, A. Environmental Risk Analysis of Oil Handling Facilities in Port Areas. Application to Tarragona Harbor (NE Spain). Mar. Pollut. Bull. 2015, 90, 78-87. [CrossRef] [PubMed]

5. Bedri, Z.; Corkery, A.; O'Sullivan, J.J.; Deering, L.A.; Demeter, K.; Meijer, W.G.; O'Hare, G.; Masterson, B. Evaluating a Microbial Water Quality Prediction Model for Beach Management under the Revised EU Bathing Water Directive. J. Environ. Manag. 2016, 167, 49-58. [CrossRef] [PubMed]

6. Pinto, M.I.; Burrows, H.D.; Sontag, G.; Vale, C.; Noronha, J.P. Priority Pesticides in Sediments of European Coastal Lagoons: A Review. Mar. Pollut. Bull. 2016, 112, 6-16. [CrossRef] [PubMed]

7. Tavakoly Sany, S.B.; Hashim, R.; Rezayi, M.; Salleh, A.; Safari, O. A Review of Strategies to Monitor Water and Sediment Quality for a Sustainability Assessment of Marine Environment. Environ. Sci. Pollut. Res. 2014, 21, 813-833. [CrossRef] [PubMed]

8. Mujal-Colilles, A.; Gironella, X.; Sanchez-Arcilla, A.; Puig Polo, C.; Garcia-Leon, M. Erosion Caused by Propeller Jets in a Low Energy Harbour Basin. J. Hydraul. Res. 2017, 55, 121-128. [CrossRef]

9. Tsoukala, V.K.; Gaitanis, C.K.; Stamou, A.I.; Moutzouris, C.I. Wave and Dissolved Oxygen Transmission Analysis in Harbors Using Flushing Culverts: An Experimental Approach. Glob. Nest J. 2010, 12, 152-160.

10. Gaitanis, C.K.; Douka, E.; Tsoukala, V.K.; Stamou, A.I.; Moutzouris, C.I. Dissolved Oxygen Transmission in Harbor Basins Through Flushing Culverts. In Proceedings of the 11th International Conference on Environmental Science and Technology, Chania, Greece, 3-5 September 2009; pp. 285-292.

11. Schwartz, R.A.; Imberger, J. Flushing Behaviour of a Coastal Marina. Coast. Eng. Proc. 1988, 1, $2626-2640$.

12. Grifoll, M.; Jorda, G.; Borja, A.; Espino, M. A New Risk Assessment Method for Water Quality Degradation in Harbour Domains, Using Hydrodynamic Models. Mar. Pollut. Bull. 2010, 60, 69-78. [CrossRef] [PubMed]

13. Fischer, H.B.; List, E.J.; Koh, R.C.Y.; Imberger, J.; Brooks, N.H. Mixing in Inland and Coastal Waters. J. Fluid Mech. 1979, 114, 315-316.

14. DiLorenzo, J.L.; Ram, R.V.; Huang, P.; Najarian, T.O. Pollution Susceptibility of Well-Mixed Tidal Basins. J. Waterw. Port Coast. Ocean Eng. 1994, 120, 404-422. [CrossRef] 
15. Nece, B.R.E.; Asce, F.; Nece, R.E.; Asce, F. Planform Effects on Tidal Flushing of Marinas. J. Waterw. Port Coast. Ocean Eng. 1984, 110, 251-269. [CrossRef]

16. Sanford, L.P.; Boicourt, W.C.; Rives, S.R. Model For Estimating Tidal Flushing of Small Embayments. J. Waterw. Port Coast. Ocean Eng. 1992, 118, 635-654. [CrossRef]

17. Falconer, R.A.; Yu, G. Effects of Depth, Bed Slope and Scaling on Tidal Currents and Exchange in a Laboratory Model Harbour. Proc. Inst. Civ. Eng. Part 2 1991, 91, 561-576.

18. US Army Corps of Engineers. Coastal Engineering Manual; US Army Corps of Engineers: Washington, DC, USA, 2002.

19. Lončar, G.; Carević, D.; Bujak, D.; Bartolić, I.; Beg Paklar, G. Analiza Utjecaja Vjetra, Plimnih Oscilacija i Razdiobe Gustoće Na Izmjenu Mora Kroz Propuste u Marinama: Primjer Marine Ičići. Hrvat. Vode 2017, 25, 139-148.

20. Tsoukala, V.K.; Moutzouris, C.I. Wave Transmission in Harbors through Flushing Culverts. Ocean Eng. 2009, 36, 434-445. [CrossRef]

21. Fountoulis, G.; Memos, C. Optimization of Openings for Water Renewal in a Harbour Basin. J. Mar. Environ. Eng. 2005, 7, 297-305.

22. Umgiesser, G.; Ferrarin, C.; Cucco, A.; De Pascalis, F.; Bellafiore, D.; Ghezzo, M.; Bajo, M. Comparative Hydrodynamics of 10 Mediterranean Lagoons by Means of Numerical Modeling. J. Geophys. Res. Oceans 2014, 119, 2212-2226. [CrossRef]

23. Cucco, A.; Umgiesser, G. Modeling the Venice Lagoon Residence Time. Ecol. Model. 2006, 193, 34-51. [CrossRef]

24. Canu, D.M.; Solidoro, C.; Umgiesser, G.; Cucco, A.; Ferrarin, C. Assessing Confinement in Coastal Lagoons. Mar. Pollut. Bull. 2012, 64, 2391-2398. [CrossRef] [PubMed]

25. Bujak, D.; Carević, D.; Mostečak, H. Velocities inside Flushing Culverts Induced by Waves. Proc. Inst. Civ. Eng. Marit. Eng. 2017, 170, 112-121. [CrossRef]

26. Carevic, D.; Mostecak, H.; Bujak, D.; Loncar, G. Influence of Water Level Variations on Wave Transmission through Flushing Culverts Positioned in Breakwater Body. J. Waterw. Port Coast. Ocean Eng. ASCE 2018, 144, 04018012. [CrossRef]

27. Rubinić, J.; Horvat, B.; Kuhta, M.; Stroj, A. Analiza Izdašnosti Priobalnih Izvora Na Području Opatije Korištenjem Termalnih Infracrvenih Satelitskih Snimaka. In Hrvatska Konferencija o Vodama, Hrvatske Vode $i$ Europska Unija-Izazovi i Mogućnosti; CROSBI: Opatija, Hrvatska, 2007; pp. 211-216.

28. Mike 3 Flow Model. Available online: www.mikepoweredbydhi.com (accessed on 20 January 2018).

29. Song, Y.; Haidvogel, D. A Semi-Implicit Ocean Circulation Model Using a Generalised Topography-Following Coordinate System. J. Comp. Phys. 1994, 115, 228-244. [CrossRef]

30. Sleigh, D.H.; Gaskel, P.H. An Unstructured Finite Volume Algorithm for Predicting Flow in Rivers and Estuaries. Comput. Fluids 1998, 27, 479-508. [CrossRef]

31. Roe, P.L. Approximate Riemann Solvers, Parameters Vectors and Difference Schemes. J. Comput. Phys. 1981, 43, 357-372. [CrossRef]

32. Smagorinsky, J. Some Historical Remarks on the Use of Nonlinear Viscosities. In Large Eddy Simulations of Complex Engineering and Geophysical Flows; Galperin, B., Orszag, S., Eds.; Cambridge University Press: Cambridge, UK, 1993.

33. Rodi, W. Examples of Calculation Methods for Flow and Mixing in Stratified Fluids. J. Geophys. Res. 1987, 92, 5305-5328. [CrossRef]

34. Wu, J. An Estimation of Wind Effects on Dispersion in Wide Channels. Water Resour. Res. 1969, 5, 1097-1104. [CrossRef]

35. Richter, K.; Hank, T.B.; Atzberger, C.; Mauser, W. Goodness-of-Fit Measures: What Do They Tell about Vegetation Variable Retrieval Performance from Earth Observation Data. Remote Sens. Agric. Ecosyst. Hydrol. XIII 2011. [CrossRef]

36. Nash, J.E.; Sutcliffe, J.V. River Flow Forecasting through Conceptual Models Part I-A Discussion of Principles. J. Hydrol. 1970, 10, 282-290. [CrossRef]

37. Imberger, J. The Diurnal Mixed Layer. Limnol. Ocean. 1985, 30, 737-770. [CrossRef]

38. Oakey, N.S.; Elliott, J.A. Dissipation Within the Surface Mixed Layer. J. Phys. Oceanogr. 1982, 12, 171-185. [CrossRef]

39. Mike 21/SW. Available online: www.dhigroup.com (accessed on 23 January 2018). 
40. Komen, G.J.; Cavaleri, M.; Donelan, K.; Hasselman, S.; Hasselman, K.; Janssen, P.A.E.M. Modelling of Dynamic of Ocean Surface Waves; Cambridge University Press: Cambridge, UK, 1994.

41. Samaras, A.G.; Gaeta, M.G.; Miquel, A.M.; Archetti, R. High-Resolution Wave and Hydrodynamics Modelling in Coastal Areas: Operational Applications for Coastal Planning, Decision Support and Assessment. Nat. Hazards Earth Syst. Sci. 2016, 16, 1499-1518. [CrossRef]

42. Sánchez-Arcilla, A.; García-León, M.; Gracia, V. Hydro-Morphodynamic Modelling in Mediterranean Storms-Errors and Uncertainties under Sharp Gradients. Nat. Hazards Earth Syst. Sci. 2014, 14, 2993-3004. [CrossRef]

43. Brzović, N.; Strelec-Mahović, N. Modelling of Induced Circulation. WSEAS Trans. Fluid Mech. 1999, 5, 653-657.

44. Ivatek-Sahdan, S.; Tudor, M. Use of High-Resolution Dynamical Adaptation in Operational Suite and Research Impact Studies. Meteorol. Z. 2004, 13, 99-108. [CrossRef]

45. Monsen, N.E.; Cloern, J.E.; Lucas, L.V.; Monismith, S.G. A Comment on the Use of Flushing Time, Residence Time, and Age as Transport Time Scales. Limnol. Oceanogr. 2002, 47, 1545-1553. [CrossRef]

(C) 2018 by the authors. Licensee MDPI, Basel, Switzerland. This article is an open access article distributed under the terms and conditions of the Creative Commons Attribution (CC BY) license (http:/ / creativecommons.org/licenses/by/4.0/). 